\title{
Vegetation units of wetland and terrestrial habitats: the case study of Spercheios River and Maliakos Gulf (Sterea Ellas, Greece), a Natura 2000 Site
}

\author{
Maria A. Sarika ${ }^{1, *}$, Anastasia N. Christopoulou ${ }^{1,2}$, Sevasti D. Zervou ${ }^{1}$, \\ Andreas C. Zikos ${ }^{1}$
}

Keywords: flora, Greece, habitat types, river ecosystems, vegetation.

Ključne besede: flora, Grčija, habitatni tipi, rečni ekosistem, vegetacija.
Received: 13. 3. 2017

Revision received: 22. 1. 2018

Accepted: 23. 1. 2018

\begin{abstract}
The vegetation of the European Natura 2000 protected area of Spercheios river and Maliakos gulf, that includes Mediterranean sclerophyllous shrublands, as well as riverine and coastal habitats, was studied during 2000 and 2014-2015. The vegetation was analysed following the Braun-Blanquet method. Twenty six plant communities were recorded, one of which (Pistacio terebinthi-Quercetum cocciferae) described for the first time. The communities belong to fifteen alliances, fourteen orders and eleven phytosociological classes. The distinguished vegetation units are described, presented in phytosociological tables and compared with similar communities from other Mediterranean countries. Eleven different habitat types were identified. Two of them ("Quercus coccifera woods" and "Reed beds") are Greek habitat types, while the rest are included in Annex I of the Directive $92 / 43 /$ EEC. Three of the latter $(1420,2110,3170)$ have a scattered presence in the Natura 2000 network in Greece, while one (3170) is a priority habitat type.

Izvleček

V letih 2000 in od 2014 do 2015 smo preučevali vegetacijo zavarovanega Natura 2000 območja ob reki Spercheios in zalivu Maliakos, kjer so mediteranska sklerofilna grmišča, pa tudi obvodni in obalni habitati. Vegetacijo smo popisovali po Braun-Blanquetovi metodi. Našli smo 26 rastlinskih združb, eno smo opisali kot novo (Pistacio terebinthi-Quercetum cocciferae). Združbe smo uvrstili v petnajst zvez in enajst fitocenoloških razredov. Vegetacijske enote smo opisali in predstavili v fitocenoloških tabelah ter primerjali s podobnimi združbami iz drugih mediteranskih dežel. Ugotovili smo enajst habitatnih tipov. Dva med njimi ("gozdovi Quercus coccifera" and "Trstišča") sta habitatna tipa po Grški tipologiji, ostali so vključeni v Prilogo 1 Habitatne direktive (92/43/EEC). Trije habitatni tipi $(1420,2110,3170)$ se pojavljajo razpršeno v omrežju Natura 2000 v Grčiji, eden pa je prioritetni habitat (3170).
\end{abstract}




\section{Introduction}

Mediterranean rivers host diverse and dynamic plant communities, which are frequently overlooked in phytosociological studies (Ferreira \& Aguiar 2006). Though recently in Greece there is an increasing interest on the importance of riparian areas and a wide range of publications focusing on various thematic objects is available (Zaimes et al. 2011b), studies dealing with riverine vegetation are still scarce. Except of some phytosociological records included in the fundamental work of Horvat et al. (1974), information about the vegetation of Greek rivers remains limited. Data on the riparian phanerophyte flora and vegetation of some upland and lowland river systems of mainland Greece are reported by Schuler (2000), Zogaris et al. (2008, 2009), Karagianni et al. (2008), Kladis et al. (2011), Manolaki et al. (2011) and Manolaki \& Papastergiadou $(2012,2013,2016)$. The habitat types and the related vegetation of the Natura 2000 site "Stena Kalamakiou" (GR 1440004) in the plain of Thessalian Pinios river were briefly described by Theodoropoulos et al. (2006), whilst essential knowledge on land-use/vegetation cover relationships was given for the riparian areas of Nestos river (Zaimes et al. 2011a). Few studies have also focused on the vegetation of some river deltas (Babalonas 1979, Athanasiadis et al. 1996, Drossos et al. 1996, Georgiadis et al. 1997, Economidou 1998, Karagiannakidou et al. 2000, Korakis \& Gerasimidis 2006, Xystrakis et al. 2014).

The aim of the current study is to provide an inventory of vegetation and habitat types encountered in the Natura 2000 conservation area of Spercheios river and Maliakos gulf (GR2440002 Koilada kai Ekvoles Spercheiou - Maliakos Kolpos). The dominant plant communities that thrive along the valley and throughout the estuary of Spercheios river, as well as in the surrounding coastal area of Maliakos gulf, were recognized, described and classified into habitat types, according to the Directive 92/43/ EEC. Apart from the floristic and phytosociological data reported from some coastal habitats of the Spercheios river delta and of Maliakos gulf by Sarika (2012), there are no other reports concerning the vegetation of Spercheios and its deltaic system. Records on plants from the area of study are limited and mainly issued from Halácsy's work (1900-1904) and a more recent publication of KoumpliSovantzi \& Vallianatou (1994).

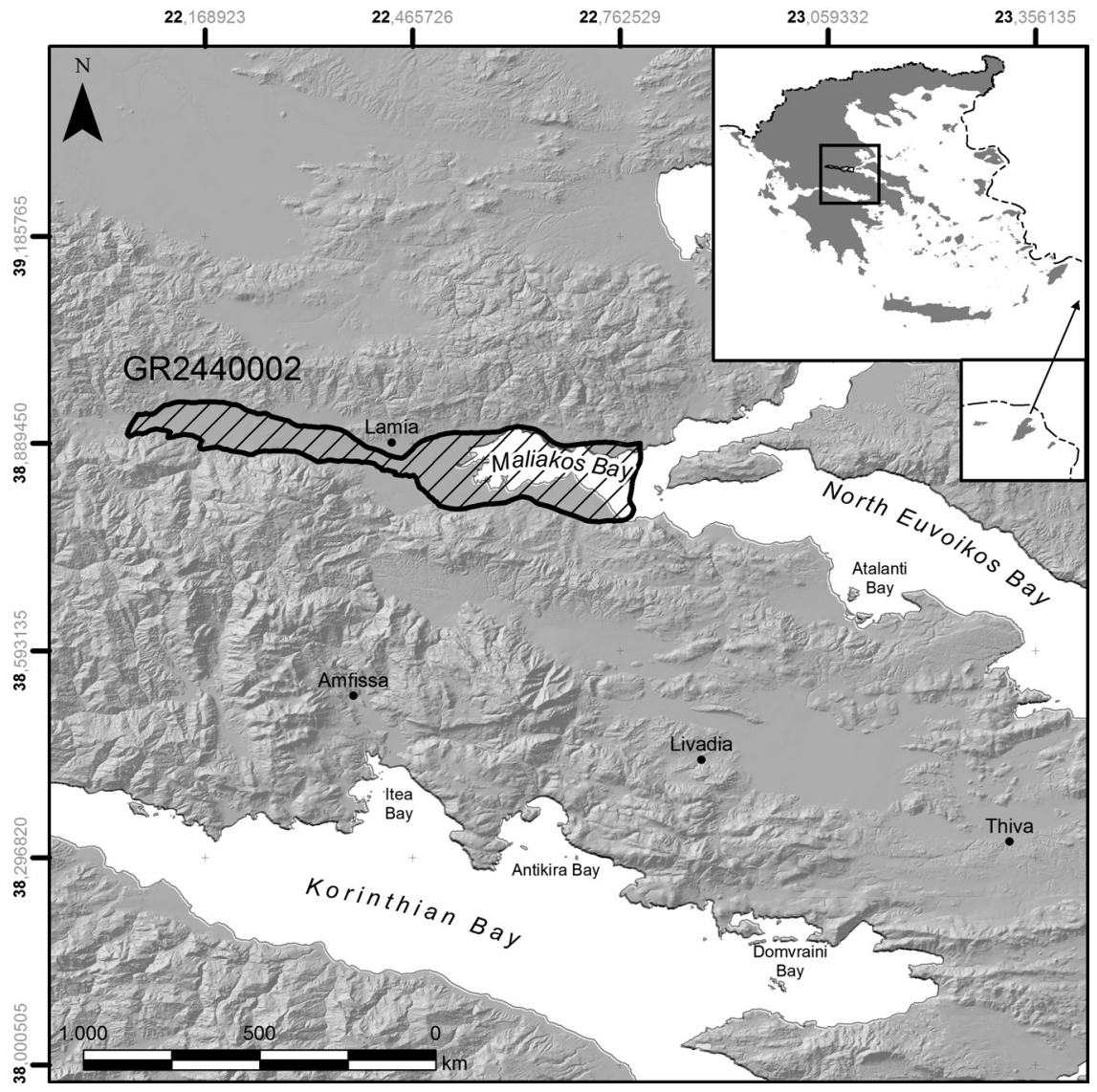

Figure 1: Study area: the Natura 2000 site "Koilada kai Ekvoles SpercheiouMaliakos Kolpos" (GR2440002) and its' location in Greece.

Slika 1: Preučevano območje Natura 2000 "Koilada kai Ekvoles Spercheiou-Maliakos Kolpos" (GR2440002) in njegova lokacija v Grčiji. 


\section{Study area}

Spercheios and its deltaic system are located in the eastern part of central Greece (Figure 1) and they have been included in the Natura 2000 network as a Site of Community Importance (SCI) and Special Area of Conservation (SAC) with the name "Koilada kai Ekvoles SpercheiouMaliakos Kolpos" and the code GR2440002, within the framework of the European Union Habitats Directive (92/43/EEC). The site is important for its avifauna, and part of it has been designed as a Special Protection Area (SPA) under the Birds Directive (Directive 2009/147/ EC) ("Koilada kai Ekvoles Spercheiou - Maliakos Kolpos" GR2440002). Three different parts can be distinguished in the site: a) Maliakos gulf, b) the estuary of Spercheios river and its surrounding area and c) Spercheios valley. Detailed information concerning the geography, geology and climate of the study area is provided by Psomiadis et al. (2004), Sigalos et al. (2010), Dimitriou et al. (2011), Efthimiou et al. (2014) and Paparrizos \& Maris (2017). The whole area of Spercheios valley is a fertile region with diverse land use, while a mosaic of natural vegetation is widespread throughout the region (Psomiadis et al. 2004). Mediterranean sclerophyllous shrublands are widely distributed in the drainage basin of Spercheios river, especially in its upper and middle watercourse, whilst riparian tree vegetation occupies extended areas at the upper part of the delta and along the river bank (mainly from Makrakomi to Mesopotamia), with a width ranging from a few up to several hundred metres. The estuary and its surrounding area form a diverse landscape, where several types of natural vegetation alternate with agricultural land, especially intensively cultivated rice fields.

It is widely known that the species richness and the cover of riverine vegetation declined in many Mediterranean rivers due to intense anthropogenic pressures, especially through the increase of cultivated land (Magdaleno et al. 2014). According to Karageorgis et al. (2008) the most important human disturbances affecting the natural environment of Spercheios watershed are mainly connected to agricultural and to a lesser extent industrial activities. Skoulikidis et al. (2009) mentioned that a significant part of the formerly extensive riparian forests and marshes in the Spercheios river basin was converted into agricultural land in the middle of the $20^{\text {th }}$ century. Other important pressures on the deltaic and riparian zone of Spercheios are the intensive irrigation, the use of fertilizers and pesticides and the disposal of urban waste, household garbage and liquid or solid industrial waste, that aggravate the quality of surface and underground waters (Dimitriou et al. 2011, Mertzanis et al. 2011).

\section{Materials and Methods}

The data concerning the vegetation and the relevant habitat types of the study area were initially collected from appropriate vegetation sample plots (77 relevés) during the spring and summer of 2000, within the framework of the "Natura 2000" Vegetation and Habitat Identification and Mapping project. Part of these data (43 relevés) that document coastal vegetation and habitats localized in Spercheios delta or in other littoral areas of Maliakos gulf have already been published (Sarika 2012). The rest of the initially collected data (34 relevés) are included in the present study, together with more recent data (82 relevés), collected during the autumn of 2014 and 2015, within the Natura 2000 Monitoring and Assessment of Conservation Status Project (2015-2020). The latter were analyzed at the same locations as the first sampling period of 2000 or, when this was not possible, at similar adjacent vegetation stands. In the current work, the description of coastal vegetation and habitat types is according to recent data, with few exceptions (2 relevés).

For the description and mapping of the prevailing vegetation units, 116 relevés were made in the field according to the Braun-Blanquet approach (Westhoff \& van der Maarel 1980, Kent \& Coker 1992). The methods of field measurements and data processing are thoroughly described by Sarika (2012). The vegetation units were defined based on an assessment of species fidelity and are given in phytosociological tables (Tables 2-10). The syntaxonomic classification follows Mucina et al. (2016). Habitats' delimitation and classification was achieved through the evaluation of the dominant vegetation types and their diagnostic species, as described in Horvat et al. (1974), Grabherr \& Mucina (1993), Mucina et al. (1993), Dimopoulos et al. (1995), Sýkora et al. (2003) and Biondi et al. (2012). The coding of the distinct habitats follows the Interpretation Manual of EU Habitat types (European Commission 2013), whereas the Greek habitat types are according to Dafis et al. (2001).

TWINSPAN (Hill \& Šmilauer 2005) was used to classify relevés. In order to avoid resulting in groups with a small number of releves, only three levels of division were applied. Consequently, Non-Metric Multidimensional Scaling (NMDS) was used in order to project classification results onto an ordination diagram, following Jasprica et al. (2015). Ordination analysis was performed in $\mathrm{R}$ statistical software package ( $\mathrm{R}$ Core Team 2017) using the 'vegan' package (Oksanen 2015). Initially, analysis included all 116 releves, but then the four Tamarix smyrnensis relevés (Table 3) were excluded. 
This was due to the fact that only four (Lolium rigidum, Cynodon dactylon, Polypogon maritimus, Phragmites australis) out of ten species recorded in the understorey were present in at least one of the other communities; Cynodon dactylon and Polypogon maritimus represent humid "ruderals" related with more than one vegetation type, while Phragmites australis can be very competitive in disturbed wet areas (Kettenring et al. 2012). As a result, analysis was based on 243 taxa and 112 relevés. The consistency between ordination distances and community dissimilarities was tested using Shepard plot in the 'vegan' package in $\mathrm{R}$, which illustrate correlation between observed dissimilarities and NMDS ordination distances.

Plant material was identified in the Institute of Systematic Botany, University of Athens. For the identification of taxa Tutin et al. $(1968-80,1993)$ was mainly used, but Davis (1965-85) and Strid \& Tan $(1997,2002)$ were also consulted. The taxonomy and nomenclature of taxa follow Dimopoulos et al. $(2013,2016)$.

\section{Results and Discussion}

\section{Flora}

During field work, a total of 249 taxa were recorded (Pteridophyta 3, Spermatophyta-Gymnospermae 1, Spermatophyta-Angiospermae 245). These are presented in Appendix 1. They belong to 63 families, 180 genera, 208 species and 35 subspecies. The family Poaceae is the most diverse (49 taxa), followed by Fabaceae (21 taxa), Asteraceae (16 taxa), Apiaceae (14 taxa), Lamiaceae (12 taxa) and Cyperaceae (11 taxa).

\section{Vegetation and habitat types}

The analysis of field data revealed a total of 16 associations, 2 subassociations and 8 communities not assigned to formal rank. They are grouped into 15 alliances, 14 orders and 11 phytosociological classes (see syntaxonomic synopsis). These syntaxa can be grouped into the following major categories: 1) syntaxa related to riverine habitats 2) syntaxa related to coastal psammophytic and halophytic habitats and 3) syntaxa related to Mediterranean sclerophyllous shrublands.

The distinguished vegetation units were classified into eleven different habitat types (Table 1). Two of them (934A, named "Quercus coccifera woods" and 72A0, named "Reed beds") are Greek habitat types (Dafis et al. 2001), while the rest are included in Annex I of the Directive 92/43/EEC. On the basis of distribution categories,
Table 1: Classification of the distinguished vegetation units into habitat types according to Council Directive 92/43/EEC. Tabela 1: Klasifikacija ugotovljenih vegetacijskih enot v habitatne tipe v skladu z Direktivo Sveta 92/43/EEC.

\section{Mediterranean sclerophylous shrublands (maquis) (habitat code: 934A, Greek Quercus coccifera woods)** Quercus coccifera community \\ Pistacio terebinthi-Quercetum cocciferae ass. nova Phillyreo latifoliae-Querco cocciferetum \\ Paliurus spina-christi-Quercus coccifera community}

Southern riparian galleries and thickets (Nerio-Tamaricetea and Securinegion tinctoriae) (habitat code: 92D0) Nerio oleandri-Viticetum agni-casti

Salix alba and Populus alba galleries (habitat code: 92A0)

Salicetum albo-fragilis

Populus alba community

Tamaricetum smyrnensis

Tamaricetum parviflorae

Tamarix tetrandra community

Oriental plane woods (Platanion orientalis) (habitat code: 92C0)

Equiseto telmateiae-Platanetum orientalis

Constantly flowing Mediterranean rivers with PaspaloAgrostidion species and hanging curtains of Salix and Populus alba (habitat code: 3280 )

Paspalo distichi-Agrostietum semiverticillati

Mediterranean temporary ponds (habitat code: 3170 )* Cyperus fuscus-Juncus hybridus community

Annual vegetation of drift lines (habitat code: 1210)

Salsolo kali-Cakiletum maritimae

Embryonic shifting dunes (habitat code: 2110)

Eryngio-Sporoboletum virgi

Mediterranean and thermo-Atlantic halophilous scrub (Salicornietea fruticosae) (habitat code: 1420)

Sarcocornietum perennis

Puccinellio convolutae-Arthrocnemetum glauci

Arthrocnemo glauci-Halocnemetum strobilacei

Limonium narbonense community

Mediterranean salt meadows (habitat code: 1410)

Juncetum maritimo-acuti

Juncus subulatus community

Reed beds (habitat code: 72A0)**

Phragmitetum communis

Phragmitetum communis elymetosum elongati

Phragmitetum communis bolboschoenetosum maritimi

Typhetum domingensis

Bolboschoenus maritimus community 
responsibility criteria and threats, as they are proposed by Dimopoulos et al. (2006) three of the detected habitat types $(3170,92 \mathrm{D} 0,934 \mathrm{~A})$ are of high and three $(1210$, $1420,2110)$ of medium monitoring importance. Three of them have a scattered distribution in Greece (1420, $2110,3170)$, while the rest are widespread or abundant. In the text and in Table 1, the priority habitat type (3170) and the Greek ones (934A, 72A0), are indicated by one or two asterisks respectively.

Out of the 116 relevés registered during field work, 24 were carried out on maquis, 47 at sites near the sea (strandline zone, coastal sand, salt marshes, salt meadows, reed beds) and 45 at sites far off the coasts (riverine scrub galleries and thickets, alluvial forests, pionner dwarf and grass vegetation on temporarily flooded soils). TWINSPAN and NMDS analysis revealed 8 groups (Figure 2). Shepard plot illustrated that observed dissimilarities and the ordination distances were highly correlated (Nonmetric fit, $\left.\mathrm{R}^{2}=0.976\right)$.

The first group (1) corresponds to the Mediterranean sclerophyllous shrublands of the order Pistacio lentisciRhamnetalia alaterni, while the second (2) to the Rubo sancti-Nerion oleandri alliance. The gallery forests of Platanus orientalis (Platanion orientalis), the willow-poplar riparian low open forests (Salicion albae) and the riparian scrub vegetation of the alliance Tamaricion parviflorae form group number three (3). The communities of coastal salt marshes (Salicornietalia fruticosae, Limonietalia),

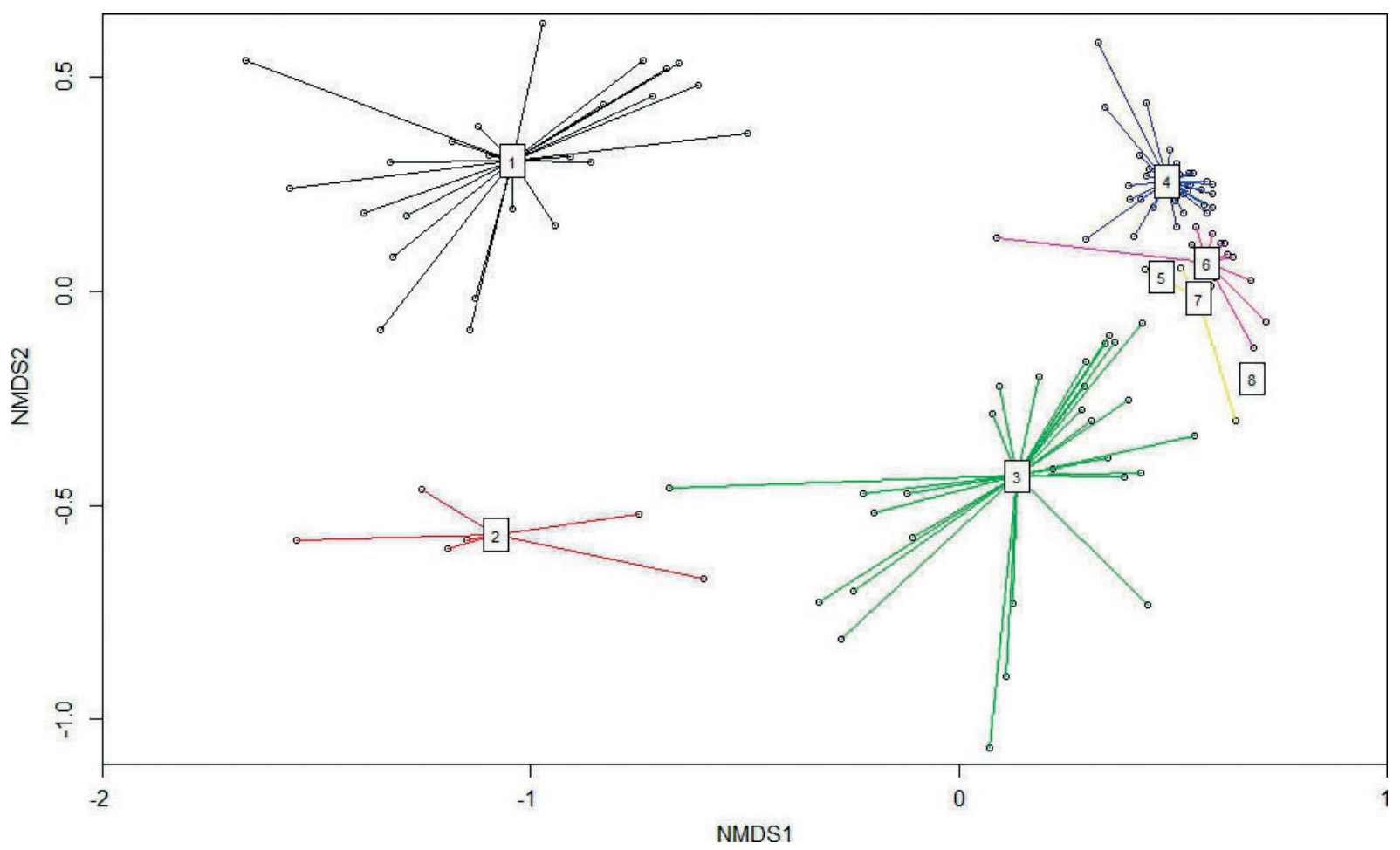

Figure 2: Nonmetric multidimensional scaling (NMDS) of 116 relevés. Group 1: 24 relevés - Mediterranean sclerophylous shrublands (habitat type 934A), group 2: 6 relevés - Southern riparian galleries and thickets (Nerio-Tamaricetea and Securinegion tinctoriae) (habitat type 92D0), group 3: 29 relevés - Salix alba and Populus alba galleries (habitat type 92A0), Oriental plane woods (Platanion orientalis) (habitat type 92C0) and the riparian scrub vegetation of the alliance Tamaricion parviflorae, group 4: 32 relevés - Mediterranean and thermo-Atlantic halophilous scrub (habitat type 1420), Mediterranean salt meadows (habitat type 1410) and Reed beds (habitat type 72A0), group 5: 1 relevé - association Typhetum domingensis (habitat type 72A0), group 6: 11 relevés - Annual vegetation of drift lines (habitat type 1210) and Embryonic shifting dunes (habitat type 2110), group 7: 8 relevés - Constantly flowing Mediterranean rivers with Paspalo-Agrostidion species and hanging curtains of Salix and Populus alba (habitat type 3280), group 8: 1 relevé - Mediterranean temporary ponds (habitat type 3170).

Slika 2: Analiza nemetričnega multidimenzionalnega skaliranja (NMDS) 116 popisov. Skupina 1: 24 popisov - Mediteranska sklerofilna grmišča (habitatni tip 934A), skupina 2: 6 popisov - Južni obrežni galerijski gozdovi in grmičevje (Nerio-Tamaricetea in Securinegion tinctoriae) (habitatni tip 92D0), skupina 3: 29 popisov - Galerijski gozdovi vrst Salix alba in Populus alba (habitatni tip 92A0), Vzhodni gozdovi platan (Platanion orientalis) (habitatni tip 92C0) in obrežna grmiščna vegetacija zveze Tamaricion parviflorae, skupina 4: 32 popisov - Mediteranska in termo-atlantska grmišča (habitatni tip 1420), Mediteranska slana travišča (habitat type 1410) in trstišča (habitatni tip 72A0), skupina 5: 1 popis - asociacija Typhetum domingensis (habitatni tip 72A0), skupina 6: 11 popisov - Enoletna vegetacija morskih obal (habitatni tip 1210) in Embrionalne nestabilne dine (habitatni tip 2110), skupina 7: 8 popisov - Stalno tekoče mediteranske reke z vrstami zveze Paspalo-Agrostidion in sestoji vrst Salix in Populus alba (habitatni tip 3280), skupina 8: 1 popis - Mediteranske občasne mlake (habitatni tip 3170). 
salt meadows (Juncion maritimi) and coastal reed beds (Phragmition, Scirpion maritimi) are placed in the fourth group (4). Typhetum domingensis, which also belongs to the Phragmition alliance, is separated in the fifth group (5). This community is rare in the study area, both in coastal and fresh water habitats. Due to accessibility difficulties, only one relevé, in a freshwater locality was performed. The sixth group (6) contains the communities of drift lines (therophytic halo-nitrophilous communities) and sandy soils near the sea (psammophilous perrenial communities of embryonic coastal dunes), which belong to the alliances Euphorbion peplidis and Ammophilion respectively. The last two groups (7 and 8) include the pioneer grass formations (hygrophilous and mesophilous meadows) of the alliance Paspalo distichi-Agrostion semiverticilati, that thrive on moist or permanently wet substrates linked to periodically submerged soils (group 7) and the pioneer dwarf cyperaceous vegetation of the alliance Nanocyperion (group 8).

Descriptions of the distinguished habitat types and the associated plant communities are presented in the following paragraphs, while the syntaxonomy of the identified communities is synoptically presented below:

QUERCETEA ILICIS Br.-Bl. ex A. Bolòs et O. de Bolòs in A. Bolòs y Vayreda 1950

PISTACIO LENTISCI-RHAMNETALIA ALATERNI

Rivas-Martínez 1975

Quercus coccifera community

Paliurus spina-christi-Quercus coccifera community

Ceratonio-Pistacion lentisci Zohary et Orshan 1959

Phillyreo latifoliae-Querco cocciferetum Quezél et Barbéro 1985

Pistacio terebinthi-Rhamnion alaterni Barbéro et Quézel 1975

Pistacio terebinthi-Quercetum cocciferae ass. nova Holotypus: Table 2, rel. 17, hoc loco

Character species: Quercus coccifera, Pistacia terebinthus, Juniperus oxycedrus.

Physiognomy and ecology: partly evergreen shrubland formation dominated by Quercus coccifera and Pistacia terebinthus, that thrives within the Mediterranean sclerophyllous evergreen pre-forest vegetation zone.

Distribution: Spercheios river valley (Greece)

NERIO-TAMARICETEA Br.-Bl. et O. de Bolòs 1958 TAMARICETALIA AFRICANAE Br.-Bl. et O. de Bolòs 1958

Rubo sancti-Nerion oleandri S. Brullo et al. 2004 Nerio oleandri-Viticetum agni-casti Paradis 2006
SALICETEA PURPUREAE Moor 1958

SALICETALIA PURPUREAE Moor 1958

Salicion albae Soó 1951

Salicetum albo-fragilis Tüxen 1948

Populus alba community

TAMARICETALIA RAMOSISSIMAE Borza et Boşcaiu ex Dolțu et al. 1980

Tamaricion parviflorae I. Kárpáti et V. Kárpáti 1961 Tamaricetum smyrnensis Seçmen et Leblebíci 1996 Tamaricetum parviflorae Kárpáti 1961

Tamarix tetrandra community

ALNO GLUTINOSAE-POPULETEA ALBAE P. Fukarek et Fabijanić 1968

POPULETALIA ALBAE Br.-Bl. ex Tchou 1949 nom. conserv. propos.

Platanion orientalis I. Kárpáti et V. Kárpáti 1961

Equiseto telmateiae-Platanetum orientalis Bergmeier 1990

BIDENTETEA Tx. et al. ex von Rochow 1951

PASPALO-HELEOCHLOETALIA Br.-Bl. ex Rivas Goday 1956

Paspalo-Agrostion semiverticillati Br.-Bl. in Br.-

Bl. et al. 1952

Paspalo distichi-Agrostietum semiverticillati Br.Bl. 1936

ISOËTO-NANOJUNCETEA Br.-Bl. et Tx. in Br.-Bl. et al. 1952

NANOCYPERETALIA Klika 1935

Nanocyperion Koch 1926

Cyperus fuscus-Juncus hybridus community

CAKILETEA MARITIMAE Tx. et Preising in Tx. ex Br.-Bl. et Tx. 1952

THERO-ATRIPLICETALIA Pignatti 1953

Euphorbion peplidis Tx. ex Oberd. 1952

Salsolo kali-Cakiletum maritimae Costa et Mansanet 1981 corr. Rivas-Martinez, Costa et Loidi 1992

AMMOPHILETEA Br.-Bl. et Tx. ex Westhoff et al. 1946 AMMOPHILETALIA Br.-Bl. et Tx. ex Westhoff et al. 1946

Ammophilion Br.-Bl. 1921

Eryngio-Sporoboletum virginici Géhu et Uslu 1989

SALICORNIETEA FRUTICOSAE Br.-Bl. et Tx. ex A. Bolòs y Vayreda et O. de Bolòs in A. Bolòs y Vayreda 1950

SALICORNIETALIA FRUTICOSAE Br.-Bl. 1933

Salicornion fruticosae Br.-Bl. 1933

Sarcocornietum perennis F. Galván \& Santos 1984

Arthrocnemion glauci Rivas-Mart. et Costa M. 1984

Arthrocnemo glauci-Halocnemetum strobilacei Oberdorfer 1952 
Puccinellio convolutae-Arthrocnemetum glauci (Br.-Bl. (1928) 1933) Géhu ex Géhu et al.1984

LIMONIETALIA Br.-Bl. et O. de Bolòs 1958

Limonium narbonense community

JUNCETEA MARITIMI Br.-Bl. in Br.-Bl. et al. 1952

JUNCETALIA MARITIMI Br.-Bl. ex Horvatić 1934

Juncion maritimi Br.-Bl. ex Horvatić 1934

Juncetum maritimo-acuti Horvatić 1934

Juncus subulatus community

PHRAGMITO-MAGNOCARICETEA Klika in Klika et Novák 1941

PHRAGMITETALIA Koch 1926

Phragmition communis Koch 1926

Phragmitetum communis Schmale 1939 typicum

Phragmitetum communis Schmale 1939 elymeto-

sum elongati

Phragmitetum communis Schmale 1939 bolboscho-

enetosum maritimi

Typhetum domingensis Brullo, Minissale \& Spampinato 1994

BOLBOSCHOENETALIA MARITIMI Hejný in Holub et al. 1967

Scirpion maritimi Dahl et Hadać 1941

Bolboschoenus maritimus community

\section{Description of habitat types}

\section{Mediterranean sclerophylous shrublands}

\section{Quercus coccifera woods \\ (habitat code: 934A) **}

This habitat type refers to tall, arborescent Quercus coccifera dominated formations. In reality, this type of vegetation is a degraded form of overgrazed oak forests, which have often been subjected to intensive timber felling as well (Korakis et al. 2015). Although this vegetation and its relative habitat type occur throughout mainland Greece and in inner sites of the largest Greek islands, they are absent from the rest of the EU countries. They are not included in Annex I of the Directive 92/43/EEC and were characterized as a "Greek habitat type" with the code 934A (Dafis et al. 2001).

In the study area, this vegetation type is mainly dominated by Quercus coccifera and is apparently diversified into four different formations. One of them consists of Quercus coccifera solely and is presented in Table 2 as the first group of relevés (1-4). Sclerophyllous formations that follow at the same table are also predominated by kermes oak and are constantly associated either with the deciduous shrub Pistacia terebinthus (relevés 5-17) or with the evergreen species Phillyrea latifolia (relevés 1822). Finally, although Quercus coccifera is always present, the species Paliurus spina-christi clearly prevails in the last formation (relevés 23-24).

Taking into consideration the dichotomous key that Rivas-Martinez (1974) proposed for the determination and classification of Quercetea ilicis vegetation units, the first group of relevés (1-4) in Table 2 could be classified to the order Pistacio lentisci-Rhamnetalia alaterni, as the association Quercetum cocciferae. Several Mediterranean Quercus coccifera dominated formations are often assigned within the Quercetum cocciferae association in its broader sense (Jasprica et al. 2016). However, the floristic composition of the Quercus coccifera relevés recorded in the Spercheios river basin was highly degraded, with a low percentage of species of the class Quercetea ilicis. Only few species, such as Asparagus acutifolius (Quercetea ilicis), Calicotome villosa (Pistacio lentisci-Rhamnetalia alaterni), Pistacia lentiscus and Myrtus communis (Oleo-Ceratonion siliquae) were sparsely present within these relevés. As a result, their precise syntaxonomic classification, in terms of alliance or association, seems to be difficult. Thus, in the present study, this type of vegetation is quoted within the order Pistacio lentisci-Rhamnetalia alaterni, as Q. coccifera community. Various, adequately similar in structure, vegetation units predominated by kermes oak are mentioned in literature from several geographic areas of Greece (e.g. Dimopoulos 1993, Georgiadis et al. 1997, Vallianatou 2005, Tsiourlis et al. 2009), but most of them are constantly associated with Pistacia lentiscus.

The presence of a partly evergreen Quercus cocciferaPistacia terebinthus shrubland community in the study area was documented by thirteen relevés (Table 2 relevés 5-17). The dominant Quercus coccifera is always associated with the deciduous shrub Pistacia terebinthus in all the representative stands of this vegetation type encountered in the Spercheios river basin. Shrubland formations of sclerophyllous evergreen species, mainly Quercus coccifera, mixed with deciduous species, such as Pistacia terebinthus, occupy large areas in Greece at low and middle altitudes (Chasapis et al. 2004). At higher altitudes, these formations penetrate the understorey of the Quercion confertae forests and at lower altitudes of the Fagion sylvaticae forests (Raus 1982, Bergmeier 1990). These shrublands have been first described by Adamović (1906), who called them pseudomaquis. Later on, many researchers (Horvat et al. 1974, Barbéro \& Quézel 1976, Raus 1980, Karagiannakidou-Iatropoulou 1983, Bergmeier 1990, Dimopoulos 1993) confirmed the secondary nature of this vegetation 
type in Greece, considering it is the substitute of degrading forest communities of Quercetalia pubescenti-petraeae. We consider that the partly evergreen Quercus cocciferaPistacia terebinthus shrubland community found in the study area belongs to the sclerophyllous pre-forest vegetation (order Pistacio lentisci-Rhamnetalia alaterni) and we suggest that it should be assigned to the alliance Pistacio terebinthi-Rhamnion alaterni.

The stands of Quercus coccifera-Phillyrea latifolia (Table 2, relevés 18-22) encountered in the study area are characterized by the constant presence of Paliurus spinachristi, Calicotome villosa and Asparagus acutifolius which occasionally participate with a high cover-abundance degree. Olea europaea subsp. europaea and Ruscus aculeatus were also recorded, with low frequency. Quercus coccifera-Phillyrea latifolia communities are among the common sclerophyllous, evergreen formations that appear in expanded areas all over Greece. Barbéro \& Quézel (1976) first described the association Querco cocciferaePhillyreetum latifoliae considering that it mainly occurs in southern Greece. They initially classified the syntaxon within the alliance Quercion ilicis, but some years later Quézel \& Barbéro (1985) reviewed this consideration, stating that when it corresponds to pre-forest formations, it must be assigned to the alliance Pistacio lentisci-Rhamnion alaterni with the name Phillyreo latifoliae-Querco cocciferetum. Many authors recorded the Querco cocciferae-Phillyreetum latifoliae or the synonymous Phillyreo latifoliae-Querco cocciferetum from several geographic areas of Greece (e.g. Knapp 1964, Bergmeier 1990, Dimopoulos 1993) and in their majority they consider that it belongs to the pre-forest vegetation of the alliance Pistacio lentisci-Rhamnion alaterni. However, according to Mucina et al. (2016) the sclerophyllous evergreen macchia of the eastern Mediterranean region belongs to the alliance Ceratonio-Pistacion lentisci.

Two out of the twenty four relevés that correspond to the sclerophyllous pre-forest vegetation of the study area are dominated by Paliurus spina-christi mixed with Quercus coccifera and Phillyrea latifolia with high cover values (Table 2, relevé 23-24). Together with Cercis siliquastrum, Pistacia terebinthus and Carpinus orientalis, Paliurus spina-christi participates in distinct syntaxa of the Illyrian shrublands found in the coastal and subcoastal sectors of the Balkans (class Crataego-Prunetea, alliance Paliuro-Petterion), commonly indicated as "Šibljak" (Blasi \& Di Pietro 2001). The Paliurus spina-christi dominated vegetation cited in the literature from many European territories was revised recently by Casavecchia et al. (2015). They identified nine different associations that are attributed to different syntaxonomic levels and amongst them a thermophilous shrub vegeta- tion type dominated by Paliurus spina-christi that occurs within a lower mesomediterranean thermotype of the Mediterranean macrobioclimate. They also recognised a strong affiliation of this type of vegetation with the order Pistacio lentisci-Rhamnetalia alaterni, and classified these communities within the alliance Oleo-Ceratonion siliquae, suballiance Oleo sylvestris-Paliurenion spinaechristi considering it includes coenoses of recovery on abandoned or burned areas. The Paliurus spina-christi formations encountered in our case affiliate to the coenoses classified by Casavecchia et al. (2015) to the alliance Oleo-Ceratonion siliquae. Some species such as Olea europaea, Crataegus monogyna, Pyrus spinosa and Smilax aspera, which according to Casavecchia et al. (2015) are characteristics and differential of the suballiance Oleo sylvestris-Paliurenion spinae-christi were found within the Paliurus spina-christi formations of the study area. We consider that our relevés belong to the pre-forest vegetation of the order Pistacio lentisci-Rhamnetalia alaterni but their assignment to the Oleo-Ceratonion siliquae alliance would be wrong, as this eastern Mediterranean alliance is only distributed to the Liguro-Tyrrhenian seaboards. Besides, the rarity and scattered occurrence of this vegetation type in the area, as well as the significantly low number of recorded relevés, make its detailed syntaxonomic classification difficult.

\section{Riverine habitats}

\section{Southern riparian galleries and thickets (Nerio-Tamaricetea and Securinegion tinctoriae) (habitat code: 92D0)}

These communities occuring in arid to dry Mediterranean bioclimates, are temporarily inundated by fresh, brackish, or saline water (Rivas-Martínez et al. 2002) and belong to the NerioTamaricetea class. Two alliances of this class, the Rubo sancti-Nerion oleandri and the Tamaricion dalmaticae, are distributed in the eastern Mediterranean region (Mucina et al. 2016). The alliance Rubo sancti-Nerion oleandri groups the thermomediterranean semiarid to dry communities developed on seasonal streambeds and could be considered as geovicariant of the west and central Mediterranean Rubo ulmifolii-Nerion oleandri (Asensi \& Diez-Garretas 2011, de Foucalt et al. 2012). The alliance Tamaricion dalmaticae includes the eastern Adriatic coast Tamarix-dominated communities, occurring within the thermo- and meso-mediterranean belts, where there are saline or sub-halophilous conditions. This alliance is considered analogous to the western Mediterranean Tamaricion africanae (Jasprica 2016). 
The Nerio oleandri-Viticetum agni-casti (Table 3, relevés 1-6), (alliance Rubo sancti-Nerion oleandri), was recognized within the riverine scrub galleries and thickets. This association is mainly localized on the pebbly edge of Spercheios riverbed, in sites with intermittent flow (near to the village Agios Sostis), but it was also encountered in oligo-halophilous coastal flats near the towns of Skarfia and Kainourgio. Karetsos (2002) cited a formation sufficiently similar to the Nerio oleandri-Viticetum agnicasti (Vitex agnus castus-Nerium oleander community) from streams confluent with Spercheios, annotating that similar vegetation units, however with a small number of relevés, have also been reported from several regions of Greece.

\section{Salix alba and Populus alba galleries (habitat code: 92A0)}

This type of riverine vegetation often grows in mosaics next to river levee pastures and is usually dominated by arborescent (in Greece exclusivelly Salix alba and S. fragilis) or shrubby (Salix ampexicaulis, S. eleagnos, S. purpurea, S. triandra) willows and tall poplars (in Greece Populus alba, P. nigra). Its' distribution is highly related to flood regime (Dimopoulos \& Bergmeier 2009). Salix and Populus riverine woods are widespread in Europe, Asia and the Near East but extensive stands of these forests are rare, especially in the Mediterranean (Dimopoulos \& Bergmeier 2009). Willows survive flooding periods up to six months, while white poplar (Populus alba) is limited to habitats with a maximum of three months of flooding (Hanganu et al. 2015).

In our case the Salix alba-Populus alba galleries consist mainly of the association Salicetum albo-fragilis (Table 4, relevé $1-13$ ) and Populus alba dominated stands (Table 4, relevé 14-15), both belonging to the alliance Salicion albae. Salicetum albo-fragilis is commonly reported from several floodplain territories of the central Balkans (Kárpáti \& Kárpáti 1961, Lasić \& Jasprica 2016). In Spercheios valley, the tree layer of Salicetum albo-fragilis is constantly enhanced by Platanus orientalis, a species of the Greek-Balkanic riparian plane forests. Rubus caesius was frequently recorded within the shrub layer of the association while in the herb layer Brachypodium sylvaticum and Equisetum arvense were faithfully present. According to literature, Salicetum albo-fragilis is the only association of the Salicion albae, recorded from Greece (Georgiadis et al. 1997, Karagianni et al. 2008), while the habitat type $92 \mathrm{~A} 0$, that this association represents, is scarcely reported (Sarika et al. 2005, Korakis \& Gerasimidis 2006, 2010).

Patchlike stands of Tamarix smyrnensis and Tamarix parviflora are frequently present at the edges or between the Salix-Populus arborescent formations, formulating the local riparian scrub vegetation. These Tamarix-dominated riverine scrub formations (Table 3, relevés 7-12) are also included within the class Salicetea purpureae, alliance Tamaricion parviflorae. They grow far away from the sea shore, in periodically inundated riverine localities and humid depressions of Spercheios valley (Loutra Ipatis, Kastri), while a Tamarix tetrandra thicket (Table 3, relevé 13) was encountered once in a slightly saline flat along the coastline, near the town of Agios Serafim. It is broadly accepted that Tamarix smyrnensis - just as the majority of the Tamarix species - is not an obligatory halophyte but a species resilient to salinity (Eberle 1975, Dafis et al. 2001). Moreover many Tamarix species, like Tamarix parviflora, are fresh water phreatophytes which occasionally occur also in saline habitats (Mullaj et al. 2007). The total lack of halophytic species from the floristic composition of the above mentioned communities underlines the consideration that they belong to the Tamaricion parviflorae alliance.

The association Tamaricetum smyrnensis, originally described from coastal saline habitats of Marmara region (Turkey), is almost exclusively accompanied by halophytic species (Alonso et al. 2014). However, the finding of Tamaricetum smyrnensis stands in Spercheios valley indicates that this syntaxon is able to grow evenly well in riverine localities periodically inundated by freshwater. We think that the eastern Mediterranean tamarisk communities of lowland water-course galleries, humid depressions and slightly saline coastal flats, which are mentioned in literature from other regions of Greece and are characterized by Tamarix smyrnensis, T. parviflora or T. tetrandra and simultaneously lack of halophytic species (Georgiadis et al. 1990, Georgiadis et al. 1997, Karagianni et al. 2008), should also be included within the alliance Tamaricion parviflorae. On the contrary, communities dominated by the same Tamarix species (Tamarix smyrnensis, T. parviflora or T. tetrandra), that occur in saline or hyper-saline coastal habitats and are characterized by an obvious abundance of halophytic species (Babalonas 1979, Korakis \& Gerasimidis 2006, Vitsou-Labraki et al. 2008) could be assigned to the class Nerio-Tamaricetea, order Tamaricetalia africanae, and Tamaricion dalmaticae alliance.

\section{Oriental plane woods (Platanion orientalis) (habitat code: 92C0)}

Platanus orientalis gallery forests are assigned to the alliance Platanion orientalis, which constitutes a characteristic vegetation type of the southern Balkan watercourses. Although these forests have a wider ecological range, resisting in more arid conditions than the Salix alba-Populus alba galleries, they demand sites with higher humidity, 
compared to communities of the class Nerio-Tamaricetea (Dimopoulos \& Bergmeier 2009). The hydrological regime, i.e. soil water level, frequency and severity of flooding, as well as a mean annual temperature higher than 11 ${ }^{\circ} \mathrm{C}$, is the most important cause of their establishment (Matevski et al. 2008, Douda et al. 2016). In the Balkans, Platanus orientalis dominated communities replace the associations of the alliance Populion albae particularly the Populetum albae (Matevski et al. 2008), which although is structurally very similar and shares many of the associated plant species (Britton \& Crivelli 1993), is restricted to the western submediterranean region (Mucina et al. 2016).

In the study area, Platanus orientalis gallery forests are still well represented, though they suffer intense anthropogenic pressure. The community that they form in Spercheios valley, approaches physiognomically and ecologically the typical Equiseto telmateiae-Platanetum orientalis, as it was originally described by Bergmeier (1990) (Table 5). It prefers sufficiently wet soils, in places periodically inundated by shallow water. Bolòs et al. (1996), taking into account relative descriptions available in literature, stated that Equiseto telmateiae-Platanetum orientalis is widely distributed around Greece (Ionian islands, Athos, Sporades, Crete) and Albania. However, according to Douda et al. (2016) the only accepted associations of the alliance Platanion orientalis are the Petasito hybridi-Platanetum orientalis and the Nerio oleandri-Platanetum orientalis.

\section{Constantly flowing Mediterranean rivers with Paspalo-Agrostidion species and hanging curtains of Salix and Populus alba (habitat code: 3280)}

This habitat type thrives on wet or temporarily flooded soils along permanently flowing Mediterranean rivers. It consists of summer-annual grass communities with Paspalum distichum and Polypogon viridis (Yalcin et al. 2014, Di Pietro et al. 2015). This pioneer vegetation, which refers to the alliance Paspalo distichi-Agrostion semiverticillati, used to be assigned within the MolinioArrhenatheretea class, order Holoschoenetalia (de Foucalt \& Catteau 2012), but this classification was not adopted by Mucina et al. (2016) as they consider it belongs to the Bidentetea class, order Paspalo-Heleochloetalia.

A community, characterized by the dominance of Paspalum distichum and the presence of several other species of the class Molinio-Arrhenatheretea, (Scirpoides holoschoenus, Mentha aquatica, Mentha longifolia, Agrostis stolonifera), grows sporadically in riverine localities of Spercheios and its tributaries (Table 6 relevés 1-8). It was encountered on damp soils, subjected to temporary flooding, par- ticularly from autumn to spring, remaining damp also in the summer, owing to the presence of a high water table. The syntaxonomic interpretation of Paspalum distichum dominated communities is not always easy to define, as it often forms monophytic or paucispecific carpets. Nevertheless, the physiognomy of the community found in the current study allows its classification within the alliance Paspalo distichi-Agrostion semiverticillati as the association Paspalo distichi-Agrostietum semiverticillati (Rivas-Martinez et al. 2001, Biondi et al. 2014, Di Pietro et al. 2015). It must also be noted that although Polypogon viridis (synonym Agrostis semiverticillata) is considered a character and diagnostic species of Paspalo distichi-Agrostietum semiverticillati, it is often absent from relevant coenoses reported in literature (Lastrucci et al. 2010a, 2010b, Fanelli et al. 2015), a fact that was observed in the relevés studied in Spercheios valley too. Formations with similar structure are rarely reported from Greece (Sarika et al. 2005), but they are fairly known from other more distant geographic areas (Biondi et al. 2003, Lastrucci et al. 2010a, 2010b, Mereu et al. 2010, Fanelli et al. 2015).

\section{Mediterranean temporary ponds (habitat code: 3170 ) *}

These seasonal wetland ecosystems are unique, due to the fact that their ecological conditions are unstable, alternating periods of flooding and drought (Grillas 2004, Silva et al. 2009). Detailed information on the Mediterranean temporary ponds, their species and vegetation diversity, as well as the reasons why these extreme habitats are considered ecosystems of conservation priority, are included in Vogiatzakis et al. (2009) Zacharias et al. (2007), Bagella et al. (2009), Grillas (2004), Silva et al. (2009). The periodically submerged soils of the Mediterranean temporary ponds usually host hygrophilous, herbaceous plant communities of the class Isoëto-Nanojuncetea but in many cases, semi-aquatic vegetation of the classes Littorelletea uniflorae and Charetea fragilis is also adapted in such environments (Bagella et al. 2009, Silva et al. 2009). Furthermore, it is well documented in literature (Bergmeier 2001, Sarika-Hatzinikolaou et. al. 2003, Zacharias et al. 2007, Vogiatzakis et al. 2009) that at the same time, several plant communities belonging to other classes, such as Potamogetonetea, Phragmito-Magnocaricetea, Molinio-Arrhenatheretea and Helianthemetea guttati, can be present in temporary ponds, either in a temporal zonation (Bagella et al. 2009) or along a smallscale zonation (Deil 2005, Bagella et al. 2007). This phenomenon is a typical feature of this type of wetlands, induced by the fluctuation of water depth and duration of flooding period (Silva et al. 2009). 
A vegetation segment, dominated by the species Cyperus fuscus and Juncus hybridus was encountered once in the study area, during the first sampling period (Table 6, relevé 9). It was located in a shallow depression, close to the main bed of Spercheios watercourse. The depression was less than one metre deep, probably filled by rainfall and presenting fluctuation in the water table. This type of Mediterranean temporary wetland vegetation belongs to the class Isoëto-Nanojuncetea, alliance Nanocyperion. Cyperus fuscus is a common species in phytocoenoses of the Nanocyperion, developing in pastures and cattle watering ponds, on alkaline or salty soils (Brullo \& Minissale 1998, Lattore et al. 2002). Communities of the Isoëto-Nanojuncetea class are scarcely reported from Greece, probably due to the ephemeral character of their life and habitat. Nevertheless, there are scattered records from western Crete (Gradstein \& Smittenberg 1977), Epirus (Sarika et al. 2005, Bergmeier \& Papaioannou 2008) and the islands Gavdos (Bergmeier 2001, Vogiatzakis et al. 2009) and Naxos (Sarika et al. 2015).

\section{Coastal psammophytic and halophytic habitats}

\section{Annual vegetation of drift lines (habitat code: 1210)}

Therophytic halo-nitrophilous vegetation, dominated by the species Salsola tragus and Cakile maritima, was found to colonize sandy/pebbly beaches in Spercheios delta, on substrates rich in sea salts and organic matter (Table 7 , relevés 1-6). This pioneer annual vegetation is grouped within the Cakiletea maritimae class, as the Salsolo kaliCakiletum maritimae, and its corresponding habitat type is distributed throughout the Greek coasts, especially in northern Greece (Géhu et al. 1986) and along the Peloponnese (Lavrentiades 1964, Spanou et al. 2006, Korakis \& Gerasimidis 2006). It is considered to be the central association of the Euphorbion peplidis alliance which is well known from coasts of Spain, Italy, Greece and Cyprus and probably has a circum-mediterranean distribution (Sýkora et al. 2003).

\section{Embryonic shifting dunes \\ (habitat code: 2110 )}

The pioneer species Elytrigia juncea, Sporobolus pungens and Eryngium maritimum, constitute the association Eryngio-Sporoboletum virginici (Table 7, relevés 7-11), which was encountered in Spercheios delta, in places temporarily inundated by the sea. This community was formerly classified within the alliance Agropyrion juncei (Sýkora et al. 2003) and later into the suballiance Sporobolenion arenarii (Biondi \& Galdenzi 2014). These authors distinguished the halo-nitrophilous herbaceous communities, which colonize the lower parts of the embryonic dunes and are sporadically inundated by the sea during storm (alliance Agropyrion juncei), from the vegetation of yellow, very permeable and humus poor mobile dunes (alliance Ammophilion). According to Mucina et al. (2016), all types of tall-grass perrenial swards on mobile white and embryonic coastal dunes of the Mediterranean are included within the alliance Ammophilion.

The Eryngio-Sporoboletum virginici and its corresponding habitat type are mentioned from mainland and insular Greece (Lavrentiades 1964, Babalonas et al. 1995, Georgiadis et al. 1997, Brofas et al. 2001, Korakis \& Gerasimidis 2006, Spanou et al. 2006, Sarika 2012), as well as from several, more distant Mediterranean coastal regions. The last two relevés of this association could be a transition towards Euphorbio paraliae-Agropyretum junceiformis, due to the dominant and constanant presence of Elytrigia juncea along with Euphorbia paralias (Šilc et al. 2016).

\section{Mediterranean and thermo-Atlantic halophilous scrub (Salicornietea fruticosae) (habitat code: 1420)}

The salt marsh vegetation of the study area is a mosaic of four different formations, mostly dominated by Sarcocornia perrenis or Arthrocnemum macrostachyum and to a lesser extent by Halocnemum strobilaceum or Limonium narbonense (Table 8). This diversification is in response to soil texture and salinity as well as to the water regime and the duration of flooding or dryness events.

As far as Sarcocornia perennis dominated stands are concerned (Table 8 , relevés $1-5$ ), they are quite similar - although less diverse - to Salicornietum radicantis reported from the Axios river delta (Oberdorfer 1952), Mesolonghi (Wolff 1968) and the Evros river delta (Babalonas 1979). The formations dominated by Sarcocornia perennis, which are usually associated with Puccinelia festuciformis and Halimione portulacoides, are amongst the most frequent and well represented phytocoenoses of this habitat type, not only in the area of the present study, but also in many other coastal regions of mainland and insular Greece (Sarika 2012, Sarika et al. 2015). Similar formations are recorded from many other geographic regions either as Salicornietum radicantis or with several synonyms of it, such as Puccinellio festuciformis-Sarcocornietum perennis (Costa et al. 2012, Sciandrello \& Tomaselli 2014). Wolff (1968) placed Salicornietum radicantis 
among the communities of the alliance Salicornion fruticosae and distinguished two variants of the association in Greece: one poor in species and the other one rich. Likewise, Rivas-Martínez et al. (2001) classified several communities dominated by Sarcocornia perennis within the Salicornion fruticosae. We consider that the Sarcocornia perennis stands found in the studied area should be assigned within the Salicornion fruticosae, as the association Sarcocornietum perennis. This association is physiognomically characterized by Sarcocornia perennis and only few companion species, including Puccinellia festuciformis and Halimione portulacoides. It must also be pointed out that a great similarity is evident between our relevés and those described by Wolff (1968) and Fernández \& Santos (1983) as Salicornietum radicantis and Sarcocornietum perennis respectively.

Communities dominated by Halocnemum strobilaceum are frequent in the eastern part of the Mediterranean (Biondi et al. 2013). The westernmost point where they were described is the coast of Tunisia (Géhu \& Géhu-Frank 1991). The association Arthrocnemo glauci-Halocnemetum strobilacei is the most widespread community that the species Halocnemum strobilaceum forms and it was first described by Oberdorfer (1952) for the north Aegean coasts. It has a central eastern European Mediterranean distribution (Biondi et al. 2013) and was found also in our study area (Table 8, relevés 10-12). In Greece, stands dominated by Halocnemum strobilaceum and/or Arhtrocnemum macrostachyum were recorded from Mesolonghi (Wolff 1968) and the island of Corfu, as Arthrocnemo glauci-Halocnemetum strobilacei (Biondi 1992), from the Evros river delta, as Halocnemetum strobilacei (Babalonas 1979) and from coastal marshy plains near the village of Oropos, as the Sarcocornia fruticosa-Halocnemum strobilaceum community (Sarika 2012). The last record concerns probably an expression of the association Salicornio fruticosae-Halocnemetum strobilacei. Wolff (1968) included all relevés dominated by Arthrocnemum macrostachyum, both the monophytic ones and those associated with Halocnemum strobilaceum, within the association Arthrocnemo glauci-Halocnemetum strobilacei considering they represent a uniform vegetation type. On the contrary, Zahran \& Willis (1992) and Batanouny (1994) reported the Arthrocnemum macrostachyum and Halocnemum strobilaceum stands found in littoral salt marshes of the whole Arab region and of the gulf of Suez (Egypt) as two different communities, occuping the same shore-line zone throughout the area sampled. We adopt the opinion of Zahran \& Willis (1992), subsequently validated by Biondi et al. (2014), accounting the monophytic stands of Arthrocnemum macrostachyum (Table 8, relevés 6-9) as a separate formation, different from the association
Arthrocnemo glauci-Halocnemetum strobilacei. We consider that the monophytic Arthrocnemum macrostachyum relevés should be referred to as Puccinellio convolutae-Arthrocnemetum glauci. This poor in other halophytic species association, is resilient to long drought periods and it is often distributed in areas subjected to anthropogenic pressures (Sciandrello \& Tomaselli 2014).

Finally, a community dominated by Limonium narbonense was sporadically encountered along the margins of coastal salt marshes of the studied area, on soils temporarily inundated but exposed to summer dryness. Tufts of this community were distributed in regions adjacent to Sarcocornia perrenis dominated patches, forming a transitional stage toward the more humid and less salt tolerant communities of Juncetea maritimi. They can be assigned to the Limonietalia order, due to the dominant species and the significant presence of Sarcocornia perrenis scrubs (Table 7 , relevés 13-15), but they are not possible to be classified in a precise association or alliance, as they are floristically poor, probably because of human disturbance.

\section{Mediterranean salt meadows (habitat code: 1410)}

This habitat includes salt meadows in the Mediterranean basin, colonized by hemicryptophytes, especially Juncus species, tolerant of saline soils, on wet and temporarily inundated sites. Two discernible formations of Juncetalia maritimi were encountered in the salt meadows of the study area, one dominated by Juncus maritimus or by $J$. acutus, representing the association Juncetum maritimoacuti (Table 9, relevés 1-4), the other dominated by $J$. subulatus (Table 9, relevés 5-8). Juncus acutus and J. maritimus are frequent in coastal wetlands of the Mediterranean region. Both species are salt tolerant and develop on permanently humid soils at the upper edges of coastal salt marshes. Juncus maritimus is more competitive than J. acutus in conditions of temporary flooding, whereas the latter tolerates water deficiency better than the former (Boscaiu et al. 2011). Juncus subulatus is also very common in coastal Mediterranean areas (Espinar et al. 2006). According to our field observations Juncus subulatus forms large dominant patches in permanently or temporarily inundated sites, closer to coastal salt marshes than the above mentioned species. More details concerning the structure and the distribution of these formations, in Greece are given by Gradstein \& Smittenberg (1977), Babalonas (1979), Georgiadis et al (1997), Korakis \& Gerasimidis (2006), Karagianni et al. (2008), Sarika (2012). 


\section{Reed beds (habitat code: 72A0) **}

Reed bed communities are among the formations dominating the vegetation physiognomy of Spercheios delta. They are also well developed in coastal wetlands and draining channels along the littoral zone of Maliakos gulf (near the villages of Skarfia and Molos), as well as at the outfall of Voagrios river. This type of vegetation, which consists of reeds and tall sedges, belongs to the class Phragmito-Magnocaricetea. Phragmitetum communis (Table 10 , relevés $1-8$ ) is the most common association of this habitat type across the coast line of the study area, forming vigorous, dense and uniform stands in shallow sites with brackish water. Except of its typical form (Table 10, relevés 4-7), two variants were also distinguished, one with Elytrigia obtusiflora subsp. obtusiflora found on the transitional zone between the upper salt marsh zone and the upland vegetation (Table 10, relevés 1-3) and the other one with Bolboschoenus maritimus growing at the outfall of Voagrios river on sites where salt and freshwater mix (Table 10, relevé 8). Phragmites australis is the main component of most European reed beds and among the most abundantly represented species in littoral wetland ecosystems (Trnka \& Prokop 2006). It forms vast "submerged" stands, in areas flooded for a long period or "terrestrial" communities, in sites with a low level of ground water for most of the time. Although its terrestrial communities are often abundantly associated with helophytic and other wetland species, the submerged ones are nearly mono-specific, because under these circumstances the common reed achieves its best vitality and is highly antagonistic (Ostendorp 1993).

The association Typhetum domingensis (Table 10, relevé 9), seems to be the most restricted and resilient element of reed bed vegetation found in our study area, as its spotlike stands develop equally well in the coastal salt marsh area of Voagrios river and in a fresh water riverine locality of Spercheios river, near the village of Kastri. This association usually occurs on muddy, often slightly saline soils that are subjected to frequent drying out and it is considered as a thermophilous vicariant of Typhetum angustifoliae (Landucci et al. 2013). Stands dominated by Typha domingensis are reported from a few Italian localities, mainly from southern and central Italy (Biondi \& Bagella 2005), Spain (Molina et al. 2003) and the coastal area bordering the Nile delta (Zahran et al. 1990). In Greece, Typhetum domingensis is probably often overlooked due to the similarity between Typha domingensis and T. angustifolia. Nevertheless, a restricted occurrence of this syntaxon is known from some lakes (Trichonis, Lisimachia, Mouria) of western Greece (Zotos 2006, Karagianni 2009).
A different type of reed bed vegetation, dominated by the species Bolboschoenus maritimus (Table 10, relevé 10), grows mainly at the outfall of Voagrios river (between the villages Agios Serafim and Kainourio), where it occurs either in sites directly connected to the sea and periodically flooded, or inland, on wet or slightly inundated soils. Bolboschoenus maritimus is sensitive to increased amounts of nutrients and is confined to coastal saline habitats or to arable land on formerly saline sites and rarely in man-made habitats (Hroudová et al. 2009, 2014). Mucina (in Balátová-Tuláčková et al. 1993) established the alliance Cirsio brachycephali-Bolboschoenion, including in it the halophilous Bolboschoenus associations described from Hungary. Later, Hroudová et al. (2009) proposed the assignment of saline, coastal Bolboschoenus maritimus associations within the alliance Scirpion maritimi, order Bolboschoenetalia maritimi, consideration adopted in the present study. Monophytic populations of Bolboschoenus maritimus are often reported from Italy, Spain and Egypt either as segments of the associations Scirpetum compacti and Bolboschoenetum maritimi or of Scirpetum compacto-littoralis (see Sarika et al. 2015). In Greece, related syntaxa are reported from Kriti (Gradstein \& Smittenberg 1977), western Greece (Wolff 1968, Georgiadis et al. 1990), Epirus (Karagianni et al. 2008) and Naxos island (Sarika et al. 2015).

\section{Temporal changes (2000 and 2014-2015) of vegetation and of the related habitat types}

Unlike the sclerophyllous and riparian vegetation of Spercheios basin, which seems to be unchanged during the last 15 years, the texture and diversity of the psamophilous and coastal wetland vegetation has undergone significant alterations. According to Nicholls et al. (2007), coasts are dynamic systems, as their form and succession are directly related to a number of geomorphological and oceanographical processes. It is also widely accepted that erosion rates and shoreline retreat increased during the second half of the twentieth century in many deltaic environments of Greece and other Mediterranean countries, due to intense anthropogenic disturbances caused in their catchments, such as the extensive river regulation and irrigation (Petropoulos et al. 2015). These shifts can directly impact the vegetation dynamics in coastal wetland and psamophytic environments (Nicholls et al. 2007). 
Data that came to light during the second sampling period indicate that reed bed communities (habitat type 72A0) localized mainly in the coastline of the studied area, appear modified compared to their former status. Out of the two previously recognized subassociations of Phragmitetum communis (Sarika 2012) only one, the elymetosum elongati (Table 9, relevés 1-3) was newly recorded, while the second (juncetosum subulati) was not rediscovered. Instead, the typical form of Phragmitetum communis (Table 9, relevé 4-7) was more common and a new subassociation, the bolboschoenetosum maritimi was found (Table 9, relevé 8). Besides alterations in the composition of the association Phragmitetum communis, the newly discovered Typhetum domingensis increases the diversity of reed bed vegetation. On the other hand, during the last fifteen years, important changes have been observed in the size of the land that reed or reed-like helophyte communities occupy in the area of study. The efficiency of reed bed formations is obviously increased nowadays compared to the past. The vigorous massive zone that they currently form spreads towards the sea, eliminating other formerly existing habitat types. From a total of seven coastal habitat types recorded in the area during the field work of 2000 , two were actually lost as they have not been detected again. These missing habitats consisted of ephemeral therophytic communities (Malcolmietalia grasslands, habitat code: 2230) or of annual succulent halophytes (Therosalicornietea, habitat code: 1310), that were formerly present on coastal sands and dunes with salt spray and on the uppermost zones of the tidal mudflats, respectively (Sarika 2012, Table 4). The temporary character of Malcolmietalia and Therosalicornietea communities, in combination with the expansive tendency of reed bed vegetation that colonizes large areas of Spercheios delta, is probably amongst the liable reasons for the loss of the above mentioned ephemeral habitats. Furthermore, according to Psomiadis et al. (2006), different human impacts (formation of an artificial - anthropogenic environment, with a dense network of roads, irrigation and drainage canals and embankments), as well as geomorphological processes (erosion, deposition) occurring in the deltaic area of Spercheios river, lead to the destabilization of the coastal zone and to a setback of the rate of advance of the coast line towards the sea (regression tendency of the coastline).

Likewise, in the salt marshes (habitat type 1420) of the area, only two - Arthrocnemum macrostachyum comm. and Sarcocornia perennis-Halimione portulacoides comm. - out of three previously reported communities (Sarika 2012, Tables 5 \& 6) were registered again. During the sampling period of 2014 and 2015 these communities were well documented by a sufficient number of relevés and at the present study they are mentioned as the associations Puccinellio convolutae - Arthrocnemetum glauci and Sarcocornietum perennis respectively. The third one from the formerly recorded salt marsh communities - a Limonium gmelinii dominated formation - was not rediscovered. Instead, the association Arthrocnemo glauciHalocnemetum strobilacei and the Limonium narbonense community were newly identified.

Other syntaxa quoted in the text, not included in Mucina et al. (2016)

Euphorbio paraliae-Agropyretum junceiformis Tüxen in Br.-Bl. \& Tüxen 1952 corr. Darimont, Duvigneaud \& Lambinon 1962

Bolboschoenetum maritimi Eggler 1933

Charetea fragilis Fukarek ex Krausch 1964

Halocnemetum strobilacei (Keller 1928) E. Topa 1938

Nerio oleandri-Platanetum orientalis Kárpáti et Kárpáti 1961

Oleo sylvestris-Paliurenion spinae-christi Biondi, Casavecchia, Biscotti \& Pésaresi 2014

Petasito hybridi-Platanetum orientalis Kárpáti et Kárpáti 1961

Populetum albae Br.-Bl. ex Tchou 1948

Puccinellio festuciformis-Sarcocornietum perennis (Br.-Bl. 1931) Géhu 1976

Quercetum cocciferae Br.-Bl. 1924

Querco coccifereae-Phillyreetum latifoliae Barbéro \& Quézel 1976

Salicornio fruticosae-Halocnemetum strobilacei Riguel 1968 Salicornietum radicantis Br.-Bl. (1931) 1952

Scirpetum compacti Van Langendonck 1931 corr. Bueno \& F. Prieto in Bueno 1997

Scirpetum compacto-litorallis (Br.-Bl. in Br.-Bl. Et al. 1952) O. de Bolòs 1962 corr. Rivas-Martínez, Costa, Castroviejo et E. Valdés 1980

Sporobolenion arenarii Géhu ex Biondi \& Galdenzi 2014 Typhetum angustifoliae Lang 1973

\section{Acknowledgments}

The floristic, phytosociological and habitat records given in the present study are based on data collected within the framework of the Natura 2000 Vegetation and Habitat Identification and Mapping project. The authors would like to thank Prof. Kyriacos Georghiou, scientific coordinator of the project for the University of Athens. Additional thanks to Urban Šilc and two anonymous reviewers for their valuable comments on an earlier version of the manuscript. 


\section{References}

Adamović, L. 1906: Über eine hischer nicht unterschiedene Vegetationsformation der Balkan halbinsel, die Pseudomacchie. Verh. Zool.-Bot. Ges. Wien 56: 355-360.

Alonso, M.A., Vicente, A., Luis Villar, J, Juan A. \& Crespo, M.B. 2014: Remarks on the Tamaricion tetragynae Zohary 1949 Alliance in the Eastern Mediterranean. In: Alonso Vargas, A., Ghezlaoui, B-E. \& Gallardo, A.J. (eds.): Ecología de Halófitos en Hábitats Mediterráneos. Universidad de Alicante, Alicante, pp. 215-225.

Asensi, A. \& Diez-Garretas, B. 2011: The Tamaricetalia order in the Western Mediterranean region. Plant Biosystems 145: 123-131.

Athanasiadis, N., Theodoropoulos, K., Eleftheriadou, E. \& Drossos, E. 1996: Forest plant communities of delta of Thessalian Pinios River (Thessalia, Hellas). Scientific Annals of the Department of Forestry and Natural Environment, Thessaloniki 39 (2): 88-902. (in Greek).

Babalonas, D. 1979. Phytosociological study of the vegetation of Evros Delta. Ph.D. Thesis, Aristotle University of Thessaloniki, Greece. (in Greek).

Babalonas, D., Sýkora, K. V. \& Papastergiadou, E. S. 1995: Review of plant communities from Greek dunes and salt marshes, a preliminary summarizing list. Ann. Bot. Roma 53: 107-117.

Bagella, S., Caria, M. C., Farris, E. \& Filigheddu, R. 2007: Issues related to the classification of Mediterranean temporary wet habitats according with the European Union Habitats Directive. Fitosociologia 44 (2) suppl. 1: 245-249.

Bagella, S., Caria, M.C., Farris, E. \& Filigheddu, R. 2009: Phytosociological analysis in Sardinian Mediterranean temporary wet habitats. Fitosociologia 46 (1): 11-26.

Balátová-Tuláčková, E., Mucina, L., Ellmauer, T. \& Wallnöfer, S. 1993: Phragmiti-Magnocaricetea. In: Grabherr, G. \& Mucina, L. (eds.): Die Pflanzengesellschaften Österreichs, Teil II., Natürliche waldfreie Vegetation. Gustav Fischer Verlag, Jena/Stuttgart/New York, pp. 79-130.

Barbéro, M., \& Quézel, P. 1976: Les groupements forestiers de Grece Centro-Méridionale. Ecologia Mediterranea 2: 1-86.

Batanouny, K.H. 1994: Halophytes and halophytic plant communities in the Arab region. In: Squires, V.R. \& Ayoub, A.T. (eds.): Halophytes as a resource for livestock and for rehabikitation of degraded lands. Kluwer Academic Publications, pp. 139-163.

Bergmeier, E. 1990: Wälder und Gebüsche des Niederen Olymp (Kato Olimbos, NO-Thessalien). Ein Beitrag zur systematischen und orographischen Vegetationsgliederung Griechenlands. Phytocoenologia 18: $161-342$.

Bergmeier, E. 2001: Seasonal pools in the vegetation of Gavdos (Greece) - in situ conservation requiered. Bocconea 13: 511-516.

Bergmeier, E. \& Papaioannou, H. 2008: Rizina marsh - a brief profile of a unique subalpine wetland in NW Greece. In: Dengler, J., Dolnik, C. \& Trepel, M. (eds.): Flora, Vegetation and Nature Conservation from Schleswig-Holstein to South America-Festschrift for Klaus Dierßen on Occasion of his $60^{\text {th }}$ Birthday. Mitt. Arbeitgem. Geobot. Schleswig-Holstein Hamb. 65: 287-300.

Biondi, E. 1992: The vegetation of sedimentary low coasts in Corfu island. Coll Phytosoc XIX: 401-427.
Biondi, E. \& Bagella, S. 2005: Vegetation and plant landscape of the Madallena archipelago (North-Eastern Sardinia). Fitosociologia 49 (2) suppl. 1:3-99.

Biondi, E. \& Galdenzi, D. 2014: Syntaxonomic considerations of the Mediterranean vegetation dominated by perennial psammophilous graminaceous plants. Plant Sociology 51 (1): 25-32.

Biondi, E., Blasi, C., Allegrezza, M., Anzellotti, I., Azzella, M.M., Carl, E., Casavecchia, S., Copiz, R., Del Vico, E. \& Zivkovic, L. 2014: Plant communities of Italy: the Vegetation Prodrome. Plant Biosystems 148 (4): 728-814.

Biondi, E., Burrascano, S., Casavecchia, S., Copiz, R., Del Vico, E., Galdenzi, D., Gigante, D., Lasen, C. Spampinato, G., Venanzoni, R., Zivkovic, L. \& Blasi, C. 2012: Diagnosis and syntaxonomic interpretation of Annex I Habitats (Dir. 92/43/EEU) in Italy at the alliance level. Plant Sociology 49 (1): 5-37.

Biondi, E., Cassavecchia, S., Estrelles, E. \& Soriano, P. 2013: Halocnemum M. Bieb. Vegetation in the Mediterranean Basin. Plant Biosystems 147 (3): 536-547.

Biondi, E., Vagge, I., Baldoni, M. \& Taffetani, F. 2003: Biodiversità fitocenotica e paesaggistica dei fiumi dell'Italia centro-settentrionale: aspetti fitosociologici e sinfitosociologici. Studi Trent. Sci. Nat., Acta Biol. 80: 13-21.

Blasi, C. \& Di Pietro, R. 2001: Sulla presenza di una nuova associazione a Paliurus spina-christi L. nel Lazio meridionale. Inform. Bot. Ital. 33(2): 407-415.

Bolòs de, O., Masalles, R.M., Ninot, J.M. \& Vigo, J. 1996: A survey on the vegetation of Cephalonia (Ionian Islands). Phytocoenologia 26 (1): 81-123.

Boscaiu, M., Ballesteros, G., Naranjo, M.A., Vicente, O \& Boira, H. 2011: Responses to salt stress in Juncus acutus and J. maritimus during seed germination and vegetative plant growth. Plant Biosystems 145 (4): 770-777.

Britton, R.H. \& Crivelli, A.J. 1993: Wetlands of southern Europe and North Africa: Mediterranean wetlands. In: Whigman, D., Dykyjova, D. \& Hejny, S. (eds.): Wetlands of the world 1: Inventory, ecology and management (Handbook of vegetation science). Springer Science, Dordrecht, pp. 129-194.

Brofas, G., Karetsos, G., Panitsa, M. \& Theodoropoulos, M. 2001: The flora and vegetation of Gyali island, SE Aegean, Greece. Willdenowia 31: 51-70.

Brullo, S. \& Minissale, P. 1998: Considerazioni sintassonomiche sulla classe Isoeto-Nanojuncetea. Intinera Geobotanica 11: 263-290.

Casavecchia, S., Biscotti, N., Pesaresi, S. \& Biondi, E. 2015: The Paliurus spina-christi dominated vegetation in Europe. Biologia 70 (7): 879-892.

Chasapis, M., Karagiannakidou, V. \& Theodoropoulos, K. 2004: Phytosociological research of Quercus coccifera $\mathrm{L}$. pseudomaquis on mount Chortiatis northern Greece. Israel Journal of Plant Sciences 52: 357-381.

Costa, J.C., Neto, C., Aquiar, C., Capelo, J., Espirito-Santo, M.D., Honrado, J., Pinto Gomes, C., Monteiro-Henriques, T., Sequeira, M. \& Lousã, M. 2012: Plant communities in Portugal (Continental, the Azores \& Madeira). Global geobotany 2: 1-180.

Dafis, S., Papastergiadou, E., Lazaridou, E. \& Tsiafouli, M. 2001: Technical manual of mapping of Greek habitat types. Greek BiotopeWetland Centre (EKBY), Thessaloniki, 393 pp. 
Davis, P. H. (ed.) 1965-85: Flora of Turkey and the East Aegean islands $1-9$. Edinburgh.

Deil, U. 2005: A review on habitats, plant traits and vegetation of ephemeral wetlands - a global perspective. Phytocoenologia 35 (2-3): 533-705.

Di Pietro, R., Theurillat, J.-P., Capelo, J., Fernández-González, F., Terzi, M., Čarni, A. \& Mucina, L. 2015: Nomenclature and syntaxonomic notes on some high rank syntaxa of the European grassland vegetation. Lazaroa 36: 79-106.

Dimitriou, E., Mentzafou, A., Tzortziou, M. \& Zeri, Ch. 2011: Environmental monitoring and pollution pressures identification in Spercheios river catchment. In: Kungolos, A., Karagiannidis, A., Aravossis, K., Samaras, P. \& Schramm, K.W. (eds.): Proceedings of the $3^{\text {rd }}$ International CEMEPE \& SECOTOX Conference, Skiathos, Greece, pp. 232-328.

Dimopoulos, P. 1993: Floristic and phytosociological research of mount Killini. Ph.D. Thesis, University of Patras. (in Greek).

Dimopoulos, P. \& Bergmeier, E. 2009: Riparian Woody Vegetation in Greece. In: Sustainable Riparian Zones: A Management Guide. (eds. Arizpe D., Mendes A., Rabaça J.E.) Ripidurable, Alpiarça, Portugal, 84-87.

Dimopoulos, P., Papastergiadou, E., Sýkora, K., Georgiadis, T., Babalonas, D. \& Dafis, S. 1995: Collection and analysis of phytosociological data on the vegetation of Greece. Goulandris Natural History Museum and Greek Biotope-Wetland Centre (EKBY), Thessaloniki, $94 \mathrm{pp}$.

Dimopoulos, P., Raus, Th., Bergmeier, E., Constantinidis, Th., Kokkini, S., Strid, A. \& Tzanoudakis, D. 2013: Vascular plants of Greece: An annotated checklist. Berlin: Botanischer Garten und Botanisches Museum Berlin-Dahlem, Athens: Hellenic Botanical Society. [Englera 31], $372 \mathrm{pp}$.

Dimopoulos, P., Raus, Th., Bergmeier, E., Constantinidis, Th., Iatrou, G., Kokkini, S., Strid, A. \& Tzanoudakis, D. 2016: Vascular plants of Greece: An annotated checklist. Supplement. Willdenowia 46: 301-347.

Dimopoulos, P., Bergmeier, E. \& Fischer, P. 2006: Natura 2000 Habitat Types of Greece evaluated in the light of distribution, threat and responsibility. Biology and Environment: Proceedings of the Royal Irish Academy 106B (3): 175-187.

Douda, J., Boublík, K., Slezák, M., Biurrun, I., Nociar, J., Havrdová, A., Doudová, J., Aćić, S., Brisse, H., Brunet, J., Chytrý, M., Csiky, J., Didukh, Y., Dimopoulos, P., Dullinger, S., Fitz Patrick Ú., Guisan A., Horchler P.J., Hrivnák R., Jandt U., Kącki Z., Kevey B., Landucci F., Lecomte H., Lenoir J., Paal J., Paternoster D., Pauli H., Pielech R., Rodwell J.S., Roelandt B., Svenning J-Ch., Šibík J., Šilc U., Škvorc Z., Tsiripidis I., Tzonev R.T., Wohlgemuth Th. \& Zimmermann, N.E. 2016: Vegetation classification and biogeography of European floodplain forests and alder carrs. Applied Vegetation Science 19: 147-163.

Drossos, E., Athanasiadis, N., Theodoropoulos, K. \& Eleftheriadou, E. 1996: Ammophilous, halophilous and hydrophilous plant communities of Delta of Thessalian Pinios River (Thessalia, Hellas). Sci. Ann. Dep. For. Nat. Env. 39: 329-365.

Eberle, G. 1975: Pflanzen am Mittelmeer (Mediterrane Pflanzengemeinschaften italiens und Griechenlands mit Ausblick auf das ganze Mittelmeergebiet). W. Kramer, Frankfurt, 276 pp.
Economidou, E. 1998: Flora, Vegetation and ecological management of Kalamas River Delta. In: Tsekos I., Moustakas M. (eds.) Progress in Botanical Research. Springer Dordrecht, pp. 53-56.

Efthimiou, G., Topologlou, Ch., Monachou, S. \& Kaprana, K. 2014: Chang detection in Natura 2000 area of Spercheios River in Central Greece using remote sensing and GIS. Journal of International Scientific Publications. Ecology and Safety 8: 259-264.

Espinar, J.L., García, L.V., Figuerola, J., Green, A.J. \& Clemente, L. 2006: Effects of salinity and ingestion by ducks on germination patterns of Juncus subulatus seeds. Journal of Arid Environments 66: 376-383.

European Commission, 2013: Interpretation manual of European Union habitats. EUR 28. European Commission, DG Environment, $144 \mathrm{pp}$.

Fanelli, G., de Sanctis, M., Gjeta, E., Mullay, A. \& Attore, F. 2015: The vegetation of the Buna River protected landscape (Albania). Hacquetia 15 (1): 1-46.

Fernández, M. \& Santos, A. 1983: La vegetación del litoral de Canarias, I. Arthrocnemetea. Lazaroa 5: 143-155.

Ferreira, M.T. \& Aquiar, F.C. 2006: Riparian and aquatic vegetation in Mediterranean-type streams (Western Iberia). Limnetica 25 (1-2): $411-424$.

de Foucalt, B., Bensettiti, F., Noble, V. \& Paradis, G. 2012 : Contribution au prodrome des végétations de France : Les Nerio oleandri-Tamaricetea africanae Braun-Blanq. \& O. de Bolós 1958. J. Bot. Soc. Bot. France 58:41-54.

de Foucalt, B. \& Catteau, E. 2012: Contribution au prodrome des végétations de France : les Agrosietea stolonifeae Oberd. 1983. J. Bot. Soc. Bot. France 59: 5-131.

Géhu, J. M., Biondi, E., Géhu-Franck, J. \& Arnold-Apostolides, N. 1986: Données synsystematiques et synchorologiques sur la vegetation du littoral sedimentaire de la Grèce continentale. Documents Phytosociologiques. N. S. Camerino 10: 43-92.

Géhu, J.-M. \& Géhu-Frank, J. 1991: Données synsystématiques et synchorologiques sur la végétation du littoral Tunisien de Bizerte a Gabes. Documents Phytosociologiques. N. S. Camerino 13: 297-315.

Georgiadis, Th., Dimopoulos, P. \& Dimitrelos, G. 1997: The flora and vegetation of the Acheron delta (W Greece) aiming at nature conservation. Phyton (Horn, Austria) 37: 31-60.

Georgiadis, Th., Economidou, E. \& Christodoulakis, D. 1990: Flora and vegetation of the Strofilia Coastal Area (NW Peloponnesos Greece). Phyton 30 (1): 15-36.

Grabherr, G. \& Mucina, L. (eds.) 1993: Die Pflanzengesellschaften Österreichs. Teil. II. Gustav Fischer Verlag, Jena,. 523 pp.

Gradstein, S. R. \& Smittenberg, J. H. 1977: The hydrophilous vegetation of western Crete. Vegetatio 34: 65-86.

Grillas, P. 2004: Introduction. In: Grillas, P., Gauthier, P., Yavercovski, N. \& Perennou, C. (eds.): Mediterranean Temporary Pools 1. Station Biologique de la Tour du Valat, Arles, pp. 11-12.

Halácsy, E. de 1900-1904: Conspectus Florae Graecae. Vol. 1, pp.1-576, 1900; Vol. 1 pp. 577-825,1901; Vol. 2: (612pp.) 1902; Vol.3: (519pp.) 1904. Guilelmi Engelmann, Lipsiae

Hanganu, J., Doroftei, M., Sârbu, I. \& Ştefan, N. 2015: Distribution of the vegetation within Danube Delta. In: Iordachi, C. \& van Assche, 
K. (eds.): The Biopolitics of the Danube Delta. Nature, History, Policies. Lexington Books, 441 pp.

Hill, M.O. \& Šmilauer, P. 2005: TWINSPAN for Windows version 2.3. Huntingdon and České Budějovice, Centre for Ecology and Hydrology and University of South Bohemia.

Horvat, I., Glavač, V. \& Ellenberg, H. 1974: Vegetation Südosteuropas. G. Fischer, Stuttgart, 768 pp.

Hroudová, Z., Hrivnák, R. \& Chỳtrý, M. 2009: Classification of inland Bolboschoenus-dominated vegetation in Central Europe. Phytocoenologia 39 (2): 205-215.

Hroudová, Z., Zákravský, P. \& Flegrová, M. 2014: The tolerance to salinity andnutrient supply in four European Bolboschoenus species (B. maritimus, B.laticarpus, B. planiculmis and B. yagara) affects their vulnerability orexpansiveness. Aquat. Bot. 112: 66-75.

Jasprica, N. 2016. Tamaricion dalmaticae, a new alliance from the eastern Adriatic. Hacquetia 15 (1): 27-29.

Jasprica, N., Škvorc, Ž., Dolina, K., Ruščić, M., Kovačić, S. \& Franjić, J. 2015: Composition and ecology of the Quercus coccifera L. communities along the eastern Adriatic coast (NE Mediterranean). Plant Biosystems 150 (6): 1140-1155.

Jasprica, N., Škvorc, Ž. \& Milović M. 2016: A phytosociological analysis of the Quercus coccifera $\mathrm{L}$. stands in south Albania. Hacquetia 15 (1): 49-65.

Karageorgis, A., Gardnerb, W., Georgopoulos, D., Mishonov, A., Krasakopoulou, E. \& Anagnostou, Ch. 2008: Particle dynamics in the Eastern Mediterranean Sea: A synthesis based on light transmission, PMC and POC archives (1991-2001). Deep-Sea Research 55: 177-202.

Karagiannakidou-Iatropoulou, V. 1983: Site research in Querco-Fagetea class of the Chortiatis mountain range. $\mathrm{PhD}$ Thesis, University of Thessaloniki (in Greek).

Karagiannakidou V, Konstantinou M. \& Lavrentiadou S. 2000 Flora, vegetation and ecological management of Strymon River Delta (NE Greece). $2^{\text {nd }}$ Balkan Botanical Congress. Instanbul, Turkey, pp. 257-262.

Karagianni, P. 2009: Habitat types ecology of Lake Mouria, N. Helia. Ph.D Thesis, University of Patras, Greece (in Greek).

Karagianni, P., Tiniakou, A. \& Georgiadis, Th. 2008: A distribution model of habitat types along the rivers of W. Greece: A case-study. Fresenius Environmental Bulletin 17 (6): 713-721.

Karetsos, G. K. 2002: Study of the flora and vegetation of Mount Oiti. PhD Thesis, University of Patras (in Greek with English summary).

Kárpáti I. \& Kárpáti N.V. 1961. Die zönologischen verhältnisse der Auenwälder Albaniens. Acta bot. Acadiae Scientiarum Hungaricae7: 235-301.Kent, M. \& Coker, P. 1992: Vegetation description and analysis: a practical approach. CRC Press, Boca Raton. Belhaven Press, London, 363 pp.

Kettenring, K.M, de Blois S. \& Hauber, D.P. 2012: Moving from a regional to a continental perspective of Phragmites australis invasion in North America. AoB Plants: pls040.

Kladis, G., Panitsa, M., Tsiripidis, I., Sarris, D. \& Dimopoulos, P. 2011: Vegetation ecology and diversity relationships in a riparian forest remnant of Northern Greece. Journal of Biological Research 16: $237-254$.
Knapp, R. 1964: Die vegetation von Kefallinia, Griechenland Geobotanische Untersuchung eines Mediterranen Gebietes und einige ihrer Anwendungs-Möglichkeiten in Wirtschaft und Landesplanung. Geobot. Mitt. (Giessen) 29: 1-206.

Korakis, G. \& Gerasimidis, A. 2006: Coastal and halophytic habitats and their flora in Evrotas Delta (SE Peloponnisos, Greece). Journal of Biological Research 6: 155-166.

Korakis, G. \& Gerasimidis A., 2010: Vegetation and habitat types. In: Catsadorakis G. \& Källander H. (eds.). The Dadia-LefkimiSoufli Forest National Park, Greece: Biodiversity, Management and Conservation. WWF Greece, Athens, pp. 85-93.

Korakis, G, Tsiakiris, R., Halley, J.M., Papaioannou, H \& Kati, B. 2015: Identification and composition of habitat types in eight sacred forests in the area of Konitsa and zagori, Greece. Proccedings of the $17^{\text {th }}$ Panhellenic Forestry Congress, Argostoli, Kefalonia, Octomber 4-7, 2015. Greece, pp. 790-796. (in Greek with English summary).

Koumpli-Sovantzi, L. \& Vallianatou, I. 1994: Floristic notes from aquatic stands of Central Greece (Sterea Ellas). Candollea 49: 195-207.

Landucci, F., Gigante, D., Venanzoni, R. \& Chytrý, M. 2013: Wetland vegetation of the class Phragmito-Magno-Cariceted in Central Italy. Phytocoenologia 43 (1-2): 67-100.

Lasić, A. \& Jasprica, N. 2016: Vegetation diversity of the two Dinaric karstic rivers in Bosnia and Herzegovina. Biologia 71 (7): 777-792.

Lastrucci, L., Landi, M. \& Angiolini, C. 2010a: Vegetation analysis on wetlands in a Tuscan agricultural landscape (central Italy). Biologia 65 (1): 54-68.

Lastrucci, L., Paci, F. \& Raffaeli, M. 2010b: The wetland vegetation of the Natural Reserves and neighbouring stretches of the Arno River in the Arezzo province (Tuscany, Central Italy). Fitosociologia 47 (1): $31-61$.

Lattore, P. V., Navas, P., Navas, D., Gil, Y. \& Cabezudo, B. 2002: Datos sobre la flora y vegetación de la Cuenca del Río Guadiamal (Sevilla-Huelva, España). Acta Botanica Malacitana 27: 189-228.

Lavrentiades, G. 1964: The ammophilous vegetation of the western Peloponnesos coasts. Vegetatio 12: 223-287.

Magdaleno F., Blanco-Garrido F., Bonada N. \& Herrere-Grao T. 2014: How are riparian plants distributed along the riverbank topographic gradient in Mediterranean rivers? Application to minimally altered river stretches in Southern Spain. Limnetica 33 (1): 121-138.

Manolaki P. \& Papastergiadou E. 2012: Response of aquatic macrophyte assemblages to nutrient enrichment in a lowland river basin of western Greece. Plant Biosystems 146 (4): 1064-1077.

Manolaki P. \& Papastergiadou E. 2013: The impact of environmental factors on the distribution pattern of aquatic macrophytes in a middlesized Mediterranean stream. Aquqtic Botany 104: 34-46.

Manolaki P. \& Papastergiadou E. 2016: Environmental factors influencing macrophytes assemblages in a middle-sized Mediterranean stream. River Research and Applications 32: 639-651.

Manolaki, P., Tsakiri, E. \& Papastergiadou, E. 2011: Inventory of aquatic and riparian flora of Acheron and Louros Rivers, and Zirou Lake in western Greece. Fresenius Environmental Bulletin 20 (4): 861-874.

Matevski, V., Čarni, A., Kostadinovski, M., Košir, P., Šilc, U. \& Zelnik, I. 2008: Flora and vegetation of the Macedonian Steppe. Založba ZRC, 96 pp. 
Mereu, L., Lastrucci, L. \& Viciani, D. 2010: Contributo alla conoscenza della vegetazione del fiume Pesa (Toscana, Italia Centrale). Stud. Bot. 29: 105-143.

Mertzanis, A., Papadopoulos, A., Goudelis, G., Pantera, A. \& Efthimiou, G. 2011: Human-induced impact to the environment and changes in the geomorphology: Some examples of inland and coastal environments in Greece. Journal of Ecology and the Natural Environment 3 (8): 273-297.

Molina, J. A, Cesermeiro, M. A. \& Moreno, P. S. 2003: Vegetation composition and soil salinity in a Spanish Mediterranean coastal ecosystem. Phytocoenologia 33 (2-3): 475-494.

Mucina, L., Bültmann, H., Dierßen, K., Theurillat, J.-P., Raus, Th., Čarni, A., Šumberová, K., Willner, W., Dengler, J., Gavilán García, R., Chytrý, M., Hájek, M., Di Pietro, R., Iakushenko, D., Pallas, J., Daniëls, F.J.A., Bergmeier, E., Santos Guerra, A., Ermakov, N., Valachovič, M., Schaminée, J.H.J., Lysenko, T., Didukh, Y.P., Pignatti, S., Rodwell, J.S., Capelo, J., Weber, H.E., Solomeshch, A., Dimopoulos, P., Aguiar, C., Hennekens, S.M., \& Tichý, L. 2016: Vegetation of Europe: hierarchical floristic classification system of vascular plant, bryophyte, lichen, and algal communities. Applied Vegetation Science 19 (suppl. 1): 3-264.

Mucina, L., Grabherr, G. \& Ellmauer, Th. 1993: Die Pflanzengesellschaften Österreichs. Teil. I. Anthropogene Vegetation. Gustav Fischer Verlag, Jena, Stuttgard, New York, 578 pp.

Mullaj, A., Vangjeli, J., Peci, D. \& Imeri, A. 2007: General considerations on the flora and vegetation of Albania's rivers. In: Pinna, M., Felice Uricchio, V., Michele Aresta, M. \& Basset, A. (eds): Rivers and citizens. Cross-border experiences in environmental protection and sustainable development. University of Salento, pp. 17-25.

Nicholls, R.J., Wong, P.P., Burkett V.R., Codignotto, J.O., Hay, J.E., McLean, R.F., Ragoonaden, S. \&. Woodroffe, C.D 2007: Coastal systems and low-lying areas. In: Parry, M.L., Canziani, O.F., Palutikof, J.P., van der Linden, P.J. \&Hanson, C.E. (eds.): Climate change 2007. Adaptation and Vulnerability. Contribution of Working Group II to the Fourth Assessment Report of the Intergovernmental Panel on Climate Change. Cambridge University Press, Cambridge, UK, 315-356.

Oberdorfer, E. 1952: Beitrag zur kenntnis der Nordagaischen Küstenvegetation. Vegetatio 3: 329-349.

Oksanen, J. 2015: Multivariate analysis of ecological communities in R: vegan tutorial, $43 \mathrm{pp}$.

Ostendorp, W. 1993: Reed bed characteristics and significance in landscape ecology. Limnologie aktuel 5: 149-161.

Paparrizos, S. \& Maris, F. 2017: Hydrological simulation of Sperchios River basin in Central Greece using the MIKE SHE model and geographic information systems. Applied Water Science 7 (2): 591-599.

Petropoulos, G.P., Kalivas, D.P., Griffiths, H.M. \& Dimou, P.P. 2015: Remote sensing and GIS analysis for mapping patio-temporal changes of erosion and deposition of two Mediterranean river deltas: The case of Axios and Aliakmonas rivers, Greece. International Journal of Applied Earth Observation and Geoinformation 35: 217-228.

Psomiadis, E., Migiros, G., Parcharidis, I. \& Poulos, S. 2004: Short period change detection of Spercheios lower delta area using space radar images. Bulletin of the Geological Society of Greece 36: 919-927.

Psomiadis, E., Parcharidis, I., Poulos, S., Stamatis, G., Migiros, G. \& Pavlopoulos, A. 2006: Earth observation data in seasonal and long term coastline changes monitoring the case of Spercheios river delta (central Greece). Zeitschrift fur Geomorphologie, Supplementband, 137: $159-175$.
Quézel, P. \& Barbéro, M. 1985: Carte de la végétation Potentielle de la région meéditerranéenne, fuille 1: meéditerranéenne oriental. Ed. C.N.R.S., Paris: 1-69 + carte.

Raus, Th. 1980: Die vegetation Ostthessaliens (Grichenland) III. Querco-Fagetea und azonale Gehölzgesellschaften. Bot. Jahrb. Syst. 101: 313-361.

Raus, Th. 1982: Phytogeographical circumscription of the Mediterranean area of the Balkan Peninsula and the problem of Thessalian pseudomaquis. Ecol. Mediterr. 8: 197-201.

R Core Team 2017. R: A language and environment for statistical computing. R Foundation for Statistical Computing, Vienna, Austria. URL https://www.R-project.org/.

Rivas-Martínez, S. 1974: La vegetación de la clase Quercetea ilicis en España y Portugal. Anal. Inst. Bot. Cavanilles 31(2): 205-259.

Rivas-Martínez, S., Díaz, E. T., Fernández-González, F., Izco, J., Loidi, J., Lousã, M. \& Penas, A. 2002: Vascular plant communities of Spain and Portugal addenda to the syntaxonomical checklist of 200. Itinera Geobotanica 15(1-2): 5-922.

Rivas-Martínez, S., Fernández-González, F., Loidi, J., Lousã, M. $\&$ Penas, A. 2001: Syntaxonomical checklist of vascular plant communities of Spain and Portugal to association level. Itinera Geobotanica 14: 5-341

Sarika, M, Bazos, I., Zervou, S. \& Christopoulou, A. 2015: Flora and vegetation of the European-network 'Natura 2000' habitats of Naxos island (GR 4220014) and of nearby islets Mikres Kyklades (GR 4220013), central Aegean (Greece). Plant Sociology 52(2): 3-56.

Sarika, M. 2012: Flora and vegetation of some coastal ecosystems of Sterea Ellas and eastern continental Greece. Lazaroa 33: 65-99.

Sarika, M., Dimopoulos, P. \& Yannitsaros, A. 2005: Contribution to the knowledge of the wetland flora and vegetation of Amvrakikos gulf, W Greece. Willdenowia 35: 69-85.

Sarika-Hatzinikolaou, M., Yannitsaros, A. \& Babalonas, D. 2003: The macrophytic vegetation of seven aquatic ecosystems of Epirus (NW Greece). Phytocoenologia 33: 93-151.

Schuler, A. 2000: Beobachtungen zur flora and vegetation der NestosAue in Nordost-Griecheland. Tuexenia 20: 419-427.

Sciandrello, S. \& Tomaselli, V. 2014: Coastal salt-marsh plant communities of the Salicornietea fruticosae class in Apulia (Italy). Biologia 69 (1): 53-69.

Sigalos, G., Loukaidi, V., Dasaklis, S. \& Alexouli-Livaditi, A. 2010: Assesment of the quality of the material transported downstream of Sperceios River, Central Greece. In: Koukis, G., Zelidis, A. Koukouvelas, I., Papatheodorou, G., Geraga, M. \& Zigour, V. (eds.): Proceedings of $12^{\text {th }}$ International Congress of Geological Society of Greece, Patras, May 19-22 2010, Greece, pp. 737-745.

Šilc U., Mullaj, A., Alegro, A., Ibraliu, A., Stevanović, Z.D., Luković, M. \& Stešević, D. 2016: Sand dune vegetation along the eastern Adriatic coast. Phytocoenologia 46: 339-355.

Silva, V., Pinto-Cruz, C. \& Espírito-Santo, M. D. 2009: Temporary ponds and hygrophilous grasslands plant communities in Monfurado Site of Community Importance. Lazaroa 30: 81-88.

Skoulikidis, N., Economou A.N., Gritzalis K. \& Zogaris S. 2009: Rivers of the Balkans. In: Tockner, K., Uehlinger U. \& Robinson 
C.T. (eds.): Rivers of Europe. Academic Press, Elsevier, Amsterdam, pp. 421-466.

Spanou, S., Verroios, G., Dimitrellos, G., Tiniakou, A. \& Georgiadis, Th. 2006: Notes on flora and vegetation of the sand dunes of western Greece. Willdenowia 36: 235-246.

Strid, A. \& Tan, K. 1997: Flora Hellenica. Vol. 1. Koeltz Sci. Books, Koenigstein, 547 pp.

Strid, A. \& Tan, K. 2002: Flora Hellenica. Vol. 2. Ruggell: A.R.G Gantner Verlag K.G., 511 pp.

Sýkora, K.V., Babalonas, D. \& Papastergiadou, E. 2003: Strandline and sand-dune vegetation of coasts of Greece and of some other Aegean countries. Phytocoenologia 33(2-3): 409-446.

Theodoropoulos, K., Eleftheriadou, E. \& Tsiripidis, I. 2006: Habitat types diversity of the site "Stena Kalamakiou" of the "Natura 2000" network. In: Platis, P., Sfouggaris, A., Papachristou, Th. \& Tsiontsis, A. (eds.): Proceedings of the $4^{\text {th }}$ Panhellenic Rangeland Congress, Volos, November 10-12, 2004. Greece, pp. 39-50. (in Greek with English summary).

Trnka, A. \& Prokop, P. 2006. Reedbed structure and habitat preference of reedbed passerines during the post-breeding period. Biologia 61 (2): $225-230$.

Tsiourlis, G., Konstantinidis, P. \& Xofis, P. 2009: Syntaxonomy and synecology of Quercus coccifera Mediterranean shrublands in Greece. J. Plant Biol. 52: 433-447.

Tutin, T. G., Burges, N. A., Chater, A. O., Edmonson, J. R., Heywood, V. H., Moore D. M., Valentine, D. H., Walters, S. M. \& Webb, D. A. 1968-1980: Flora Europaea. Vols. 2-5. Cambridge Univ. Press, Cambridge.

Tutin, T. G., Heywood, V. H., Burges, N. A., Moore, D. M., Valentine, D. H., Walters, S. M. \& Webb, D. A. 1993: Flora Europaea. 2nd Edition. Vol. 1. Cambridge University Press, Cambridge.

Vallianatou, I. 2005: Geobotanical study of Salamis, Egina and other islands of the Saronic Gulf (Hellas). PhD Thesis, University of Athens, Athens, Greece (in Greek, with English summary).

Vitsou-Labraki, A., Tiniakou, A. \& Georgiadis, Th. 2008: Ecological parameters of the vegetation types in the coastal areas of Strofylia and Acheloos Delta. In: Kamari, G., Bareka, P., Psaras, G., Constatninidis, Th., Dimopoulos, P. \& Kyparissis, A. (eds.): Proceedings of the $10^{\text {th }}$ Scientific Congress of the Hellenic Botanical Society, Ioannina, May 5-8, 2005, pp. 67-75 [in Greek].

Vogiatzakis, I. N., Kazakis, G. \& Chosn, D. 2009: Macrophyte community structure and species occurrence in relation to environmental determinants in the ephemeral aquatic habitats of Gavdos, Greece. Hydrobiologia 630: 127-138.

Westhoff, V. \& van der Maarel, E. 1980: The Braun-Blanquet approach. In: Whittaker, R. H. (ed.): Classification of plant communities. W Junk, The Hague, pp. 287-399.

Wolff, W. J. 1968: The halophilous vegetation of the lagoons of Mesolonghi, Greece. Vegetatio 16: 95-134.

Xystrakis, F., Theodoropoulos, K., Eleftheriadou, E., Samaras, D., Damianidis, Ch. \& Papadopoulos, Th. 2014: Succession rates and patterns twelve years after land use abandonment in the estuary of the River Aliakmon, N. Greece. Acta Bot. Croat. 73 (1): 21-35.
Yalcin, E., Kilinc, M., Kutbay, H. G. Bilgin, A. \& Kormaz, H. 2014: The lowland meadow vegetation of the Central Black Sea of Turkey. Ekologi 23 (91): 36-51.

Zacharias, I., Dimitriou, E., Dekker, A. \& Dorsman, E. 2007 : Overview of temporary ponds in the Mediterranean region: Threats, management and conservation issues. Journal of Environmental Biology 28 (1): 1-9.

Zahran, M. A., El-Demerdash, M. A \& Marhaly, I. A. 1990: Vegetation types of the deltaic Mediterranean coast of Egypt and their environment. Journal of Vegetation Science 1: 305-310.

Zahran, M. A. \& Willis, A. J. 1992: The vegetation of Egypt. Springer Science \& Business Media, 424 pp.

Zaimes, G., Gounaridis, D. \& Fotakis, D. 2011a: Assessing riparian land-use/vegetation cover along the Nestos River in Greece. Fresenius Environmental Bulletin 20 (12): 3217-3225.

Zaimes, G., Gounaridis, D., Iakovoglou, V. \& Emmanouloudis, D. 2011b: Riparian areas studies in Greece: A literature review. Fresenius Environmental Bulletin 20 (6a): 1470-1477.

Zogaris, S., Chatzinikolaou, Y. \& Dimopoulos, P. 2008: Riparian woodland flora in upland rivers of Western Greece. Mediterranean Marine Science 9 (2): 87-103.

Zogaris, S., Chatzinikolaou, Y. \& Dimopoulos, P., 2009: Assessing environmental degradation of montane riparian zones in Greece. Journal of Environmental Biology 30: 719-726.

Zotos, A. 2006: Flora, vegetation and management proposals of wet grasslands and reedbeds of lakes Trichonis and Lysimachia (W Greece). $\mathrm{PhD}$ Thesis, University of Ioannina, Agrinio, Greece (in Greek, with English summary). 


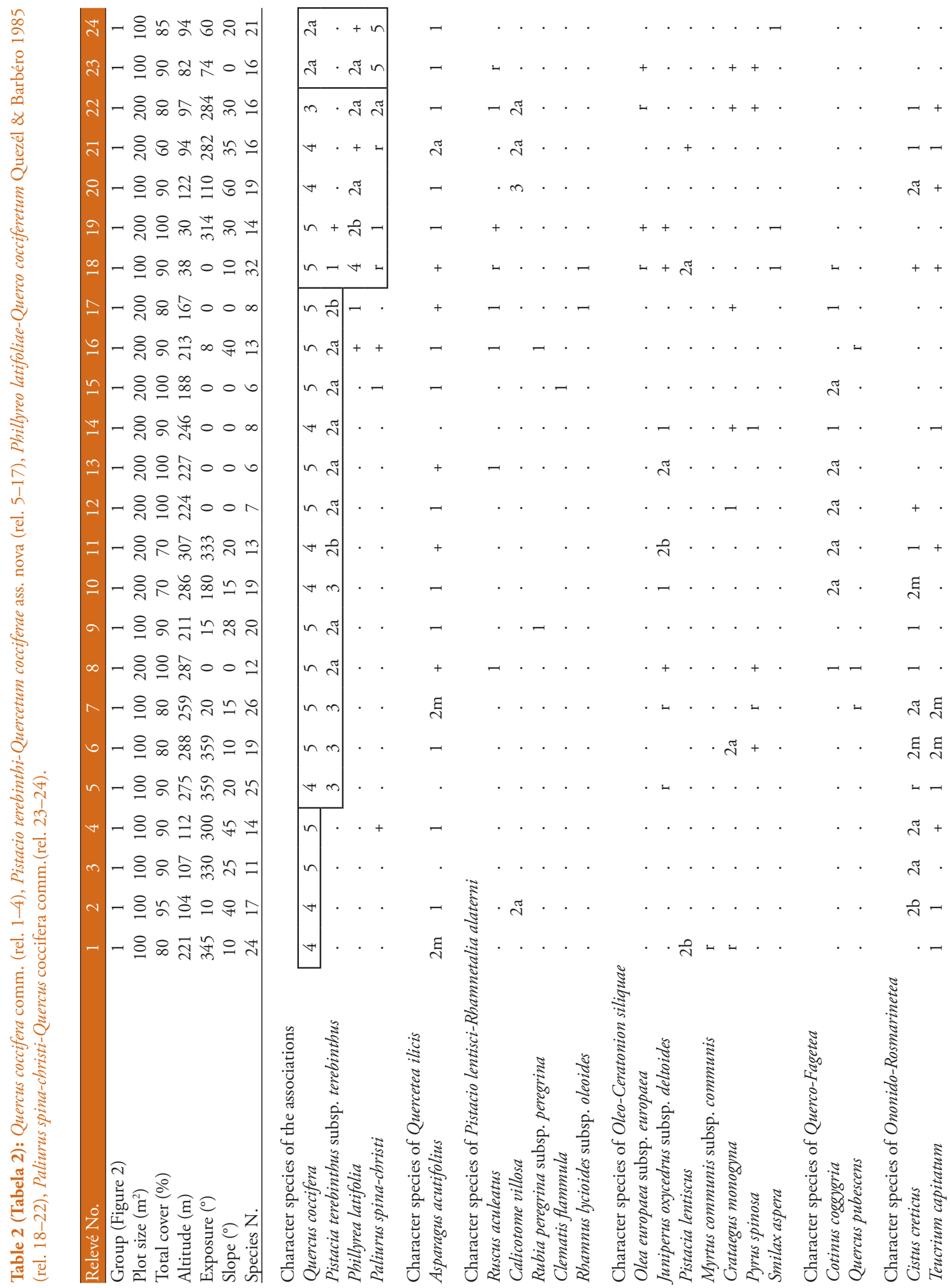




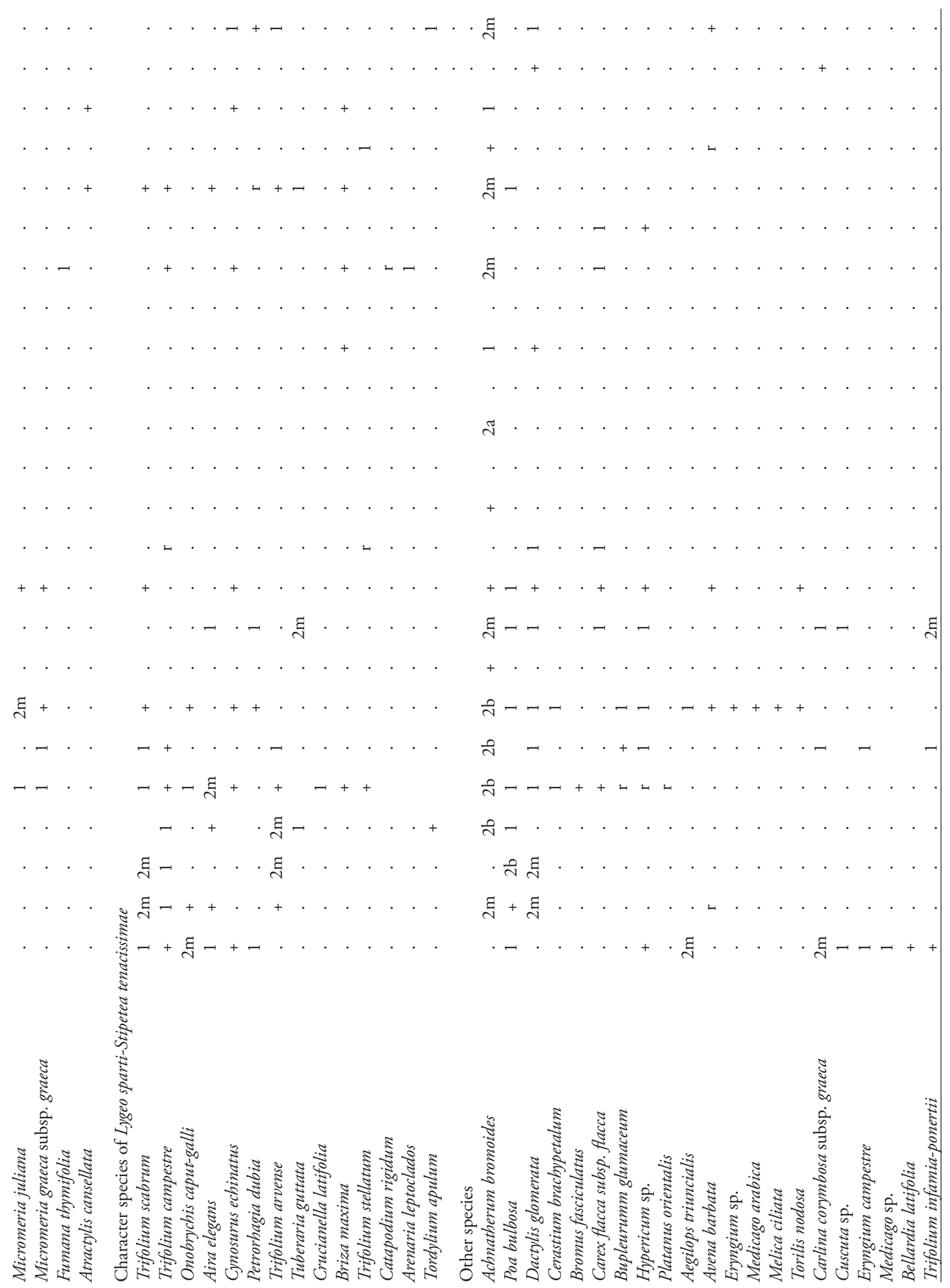




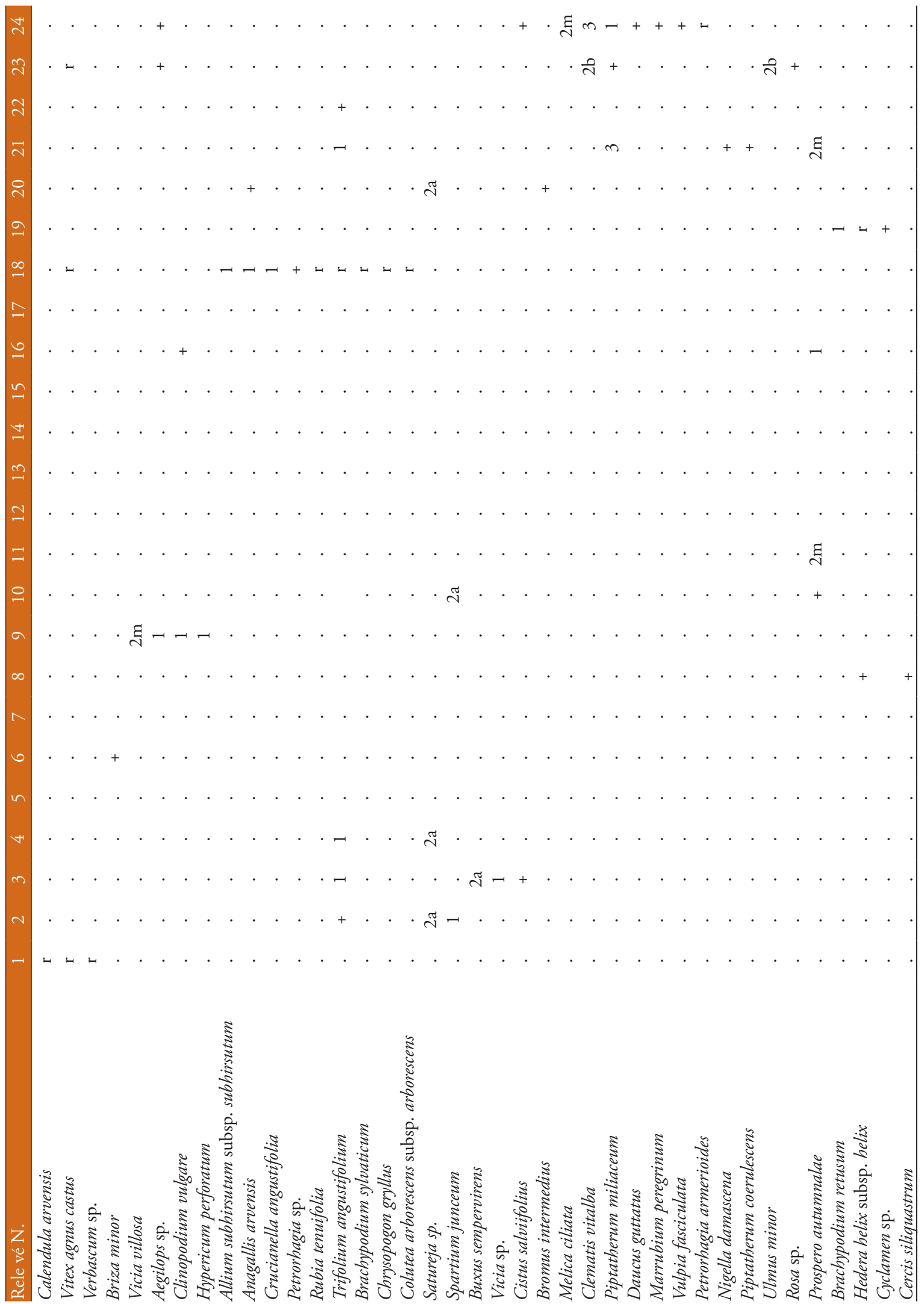


Table 3 (Tabela 3): Nerio oleandri-Viticetum agni-casti Paradis 2006 (rel. 1-6), Tamaricetum smyrnensis Seçmen \& Leblebíci 1996 (rel. 7-10), Tamaricetum parviflorae Kárpáti 1961 (rel. 11-12), Tamarix tetrandra comm. (rel. 13).

\begin{tabular}{|c|c|c|c|c|c|c|c|c|c|c|c|c|c|}
\hline Relevé N. & 1 & 2 & 3 & 4 & 5 & 6 & 7 & 8 & 9 & 10 & 11 & 12 & 13 \\
\hline Group (Figure 2) & 2 & 2 & 2 & 2 & 2 & 2 & & & & & 3 & 3 & 3 \\
\hline Plot size $\left(\mathrm{m}^{2}\right)$ & 100 & 100 & 100 & 100 & 200 & 200 & 100 & 100 & 100 & 200 & 100 & 200 & 200 \\
\hline Total cover $(\%)$ & 100 & 100 & 95 & 80 & 85 & 85 & 95 & 90 & 95 & 95 & 80 & 100 & 90 \\
\hline Altitude (m) & 167 & 167 & 142 & 134 & 140 & 135 & 47 & 55 & 56 & 44 & 84 & 84 & 1 \\
\hline Exposure & 0 & 0 & 0 & 0 & 24 & 14 & 60 & 0 & 0 & 60 & 0 & 0 & 0 \\
\hline Slope $\left(^{\circ}\right)$ & 0 & 0 & 0 & 0 & 50 & 5 & 0 & 0 & 0 & 0 & 0 & 0 & 0 \\
\hline Species N. & 27 & 22 & 22 & 16 & 10 & 10 & 5 & 5 & 5 & 6 & 13 & 9 & 10 \\
\hline
\end{tabular}

Character species of the associations

Nerium oleander subs. oleander

Tamarix smyrnensis

Tamarix parviflora

Tamarix tetrandra

\begin{tabular}{|llllll|lllllll|l|}
\hline 5 & 5 & 5 & 4 & 4 & 5 &. &. &. &. & + &. \\
\hline$\cdot$ &. &. &. &. &. & 5 & 5 & 5 & 5 &. &. &. \\
. &. &. &. &. &. &. &. &. &. & 4 & 4 &. \\
. &. &. &. &. &. &. &. &. &. &. &. & 4 \\
\hline
\end{tabular}

Character species of Nerio oleandri-Viticetalia agni-casti

Vitex agnus-castus

$\begin{array}{cccccc}. & 2 \mathrm{a} & 2 \mathrm{a} & & 2 \mathrm{~b} & . \\ . & 2 \mathrm{a} & 3 & 2 \mathrm{a} & 1 & . \\ . & & & & & \\ 2 \mathrm{~m} & 2 \mathrm{~b} & 1 & 2 \mathrm{~b} & 2 \mathrm{~m} & 2 \mathrm{~m} \\ 2 \mathrm{~m} & 2 \mathrm{~m} & . & . & . & .\end{array}$

Character species of Lygeo sparti-Stipetea tenacissimae

Trifolium scabrum

Trifolium campestre

Linum bienne

Briza maxima

Onobrychis caput-galli

Cynosurus echinatus

Catapodium rigidum

Trifolium stellatum

Linum strictum

Aira elegans

Petrorhagia dubia

Psilurus incurvus

Character species of Stellarietea mediae

Avena barbata

Lolium rigidum

Bromus madritensis

Rostraria cristata

Geranium rotundifolium

Torilis nodosa

Briza minor

Cynodon dactylon

Other species

Trifolium angustifolium

Trifolium nigrescens

Aegilops triuncialis

\begin{tabular}{|c|c|c|c|c|c|c|c|c|c|c|c|}
\hline $2 \mathrm{~m}$ & $2 \mathrm{~m}$ & . & 1 & . & 1 & . & . & . & . & 1 & \\
\hline 1 & 1 & $2 \mathrm{~m}$ & . & . & . & . & . & . & . & . & \\
\hline 1 & + & 1 & . & . & 1 & . & . & . & . & . & \\
\hline 1 & + & . & + & . & . & . & . & . & . & . & \\
\hline . & . & . & $2 \mathrm{~m}$ & . & . & • & . & . & . & . & \\
\hline 1 & . & . & . & . & . & . & . & . & . & + & \\
\hline $\mathrm{r}$ & . & . & . & . & . & . & . & . & . & . & \\
\hline . & + & . & . & . & . & . & . & . & . & . & \\
\hline . & . & . & 1 & . & . & . & . & . & . & & \\
\hline . & . & . & 1 & . & . & . & . & . & . & & \\
\hline . & . & . & + & . & - & . & . & . & . & + & \\
\hline . & . & . & . & . & . & . & $2 b$ & + & & & \\
\hline
\end{tabular}




\begin{tabular}{|c|c|c|c|c|c|c|c|c|c|c|c|c|c|}
\hline Relevé N. & 1 & 2 & 3 & 4 & 5 & 6 & 7 & 8 & 9 & 10 & 11 & 12 & 13 \\
\hline Poa bulbosa & 1 & . & . & $2 \mathrm{~m}$ & . & . & . & . & . & . & . & . & . \\
\hline Dactylis glomerata & 1 & + & 1 & & + & 1 & . & . & . & . & . & + & . \\
\hline Dasypyrum villosum & 1 & + & $\mathrm{r}$ & 1 & . & . & . & . & . & . & $2 \mathrm{~m}$ & . & . \\
\hline Daugus guttatus & 1 & . & 1 & + & . & . & . & . & . & . & . & . & . \\
\hline Gastridium ventricosum & 1 & . & . & . & . & 1 & . & . & . & . & . & . & . \\
\hline Hirschfeldia incana & . & . & . & . & . & . & . & . & . & . & . & . & . \\
\hline Polypogon maritimus & . & . & . & . & . & . & . & $2 \mathrm{~m}$ & 1 & . & . & . & . \\
\hline Trifolium lappaceum & $2 \mathrm{~m}$ & . & . & . & . & . & . & . & . & . & . & . & . \\
\hline Brachypodium sylvaticum & . & $2 \mathrm{~m}$ & + & . & . & . & . & . & . & . & . & . & . \\
\hline Centaurium erythraea & . & . & $2 \mathrm{~m}$ & . & . & . & . & . & . & . & . & . & . \\
\hline Carex flacca subsp. flacca & . & . & $2 \mathrm{~m}$ & . & . & . & . & . & . & . & . & . & . \\
\hline Bromus tectorum & . & . & . & . & . & . & . & . & . & . & $2 \mathrm{~b}$ & . & . \\
\hline Bromus intermedius & . & 1 & 1 & . & . & . & . & . & . & . & . & . & . \\
\hline Achnatherum bromoides & . & . & 1 & . & . & . & . & . & . & . & . & . & . \\
\hline Rubus sp. & . & . & . & . & . & . & . & . & . & . & . & $2 \mathrm{~m}$ & . \\
\hline Orlaya sp. & + & . & . & & $\mathrm{r}$ & + & . & . & . & . & . & . & . \\
\hline Sherardia arvensis & + & . & . & . & . & . & . & . & . & . & . & . & \\
\hline Centaurium tenuiflorum & $\mathrm{r}$ & $\mathrm{r}$ & . & . & . & $\mathrm{r}$ & . & . & . & . & . & . & \\
\hline Medicago minima & . & + & . & . & . & . & . & . & . & . & . & . & . \\
\hline Scirpoides holoschoenus & . & $\mathrm{r}$ & . & . & . & . & . & . & . & . & + & + & $\mathrm{r}$ \\
\hline Bupleurum glumaceum & . & . & $\mathrm{r}$ & . & . & . & . & . & . & . & . & . & . \\
\hline Lotus angustissimus & . & . & $\mathrm{r}$ & . & . & . & . & . & . & . & . & . & . \\
\hline Melilotus sp. & . & . & $\mathrm{r}$ & . & . & . & . & . & . & . & . & . & . \\
\hline Vicia villosa & . & . & + & . & . & . & . & . & . & . & . & . & . \\
\hline Centaurea sp. & . & . & . & 1 & . & . & . & . & . & . & . & . & $\mathrm{r}$ \\
\hline Allium sp. & . & . & . & $\mathrm{r}$ & . & . & . & . & . & . & . & . & . \\
\hline Parentucellia latifolia & . & . & . & $\mathrm{r}$ & . & . & . & . & . & . & . & . & . \\
\hline Teucrium capitatum subsp.capitatum & . & . & . & + & . & . & . & . & . & . & . & . & . \\
\hline Phragmites australis & . & . & . & . & . & . & . & + & & 1 & . & . & 1 \\
\hline Aster sp. & . & . & . & . & . & . & . & . & $\mathrm{r}$ & . & . & . & . \\
\hline Sisymbrium orientale & . & . & . & . & . & . & . & . & . & . & 1 & . & . \\
\hline Carduus pycnocephalus & . & . & . & . & . & . & . & . & . & . & 1 & . & . \\
\hline Bromus diandrus & . & . & . & . & . & . & . & . & . & . & + & + & . \\
\hline Tripidium ravennae subsp. ravennae & & . & . & . & . & . & . & . & . & . & + & $\mathrm{r}$ & . \\
\hline Rumex conglomeratus & . & . & . & . & . & . & . & . & . & . & . & + & . \\
\hline Polygonum sp. & . & . & . & . & . & . & . & . & . & . & . & $\mathrm{r}$ & \\
\hline Carlina corymbosa subsp. graeca & . & . & . & . & 1 & . & . & . & . & . & . & . & . \\
\hline Olea europaea subsp. europaea & . & . & . & . & $\mathrm{r}$ & . & . & . & . & . & . & . & . \\
\hline Anthylis hermaniae subsp. hermaniae & . & . & . & . & + & . & . & . & . & . & . & . & . \\
\hline Platanus orientalis & . & . & . & . & . & $\mathrm{r}$ & . & . & . & . & . & . & . \\
\hline Symphyotrichum squamatum & . & . & . & . & . & . & 1 & . & . & + & . & . & \\
\hline Marrubium peregrinum & . & . & . & . & . & . & . & . & . & + & . & . & . \\
\hline Hordeum murinum & . & . & . & . & . & . & $2 \mathrm{~m}$ & . & . & . & . & . & . \\
\hline Ditrichia graveolens & . & . & . & . & . & . & + & . & . & . & . & . & . \\
\hline Piptatherum miliaceum & . & . & . & . & . & . & . & . & . & . & . & . & 1 \\
\hline Sorghum halepense & . & . & . & . & . & . & . & . & . & . & . & . & $\mathrm{r}$ \\
\hline Coronilla sp. & . & . & . & . & . & . & . & . & . & . & . & . & $\mathrm{r}$ \\
\hline Daucus carota & . & . & . & . & . & . & . & . & . & . & . & . & + \\
\hline Arundo donax & . & . & . & . & . & . & . & . & . & . & . & . & + \\
\hline Foeniculum vulgare & . & & . & . & . & . & . & . & . & . & . & . & + \\
\hline
\end{tabular}


Table 4 (Tabela 4): Salicetum albo-fragilis Tüxen 1948 (rel. 1-13), Populus alba comm. (rel. 14-15).

\begin{tabular}{lccccccccccccccc}
\hline Relevé N. & 1 & 2 & 3 & 4 & 5 & 6 & 7 & 8 & 9 & 10 & 11 & 12 & 13 & 14 & 15 \\
\hline Group (Figure 2) & 3 & 3 & 3 & 3 & 3 & 3 & 3 & 3 & 3 & 3 & 3 & 3 & 3 & 3 & 3 \\
Plot size $\left(\mathrm{m}^{2}\right)$ & 200 & 200 & 200 & 200 & 200 & 200 & 200 & 200 & 200 & 200 & 200 & 200 & 200 & 200 & 200 \\
Total cover $(\%)$ & 70 & 100 & 70 & 80 & 70 & 80 & 90 & 80 & 70 & 70 & 60 & 70 & 50 & 90 & 80 \\
Altitude $(\mathrm{m})$ & 65 & 2 & 33 & 61 & 34 & 78 & 80 & 86 & 76 & 55 & 43 & 71 & 77 & 8 & 33 \\
Exposure $\left({ }^{\circ}\right)$ & 0 & 0 & 0 & 0 & 0 & 0 & 0 & 0 & 0 & 0 & 0 & 61 & 0 & 0 & 0 \\
Slope $\left({ }^{\circ}\right)$ & 0 & 0 & 0 & 0 & 0 & 0 & 0 & 0 & 0 & 0 & 0 & 5 & 0 & 0 & 0 \\
Species N. & 9 & 11 & 10 & 7 & 12 & 13 & 8 & 8 & 19 & 13 & 8 & 8 & 11 & 8 & 9 \\
\hline
\end{tabular}

Character species of the associations

Salix alba

Salix fragilis

Populus alba

Populus nigra

\begin{tabular}{|cccccccccccccc|c|}
\hline 4 & 5 & 3 & 4 & 4 & $2 \mathrm{~b}$ & $2 \mathrm{~b}$ &. &. &. &. &. &. & $2 \mathrm{a}$ \\
& + & & $2 \mathrm{a}$ & $2 \mathrm{a}$ & 3 & 4 & 4 & 3 & 4 & 4 & 4 & 3 &. \\
\hline & + & 1 &. &. &. &. &. & $\mathrm{r}$ &. &. &. &. & 4 \\
\hline
\end{tabular}

Character species of Alno glutinosae-Populetea albae

Platanus orientalis

Equisetum arvense

$\begin{array}{ccccccccccccccc}2 \mathrm{a} & + & 1 & 2 \mathrm{a} & 1 & 1 & 1 & 1 & 1 & 2 \mathrm{a} & 2 \mathrm{a} & 2 \mathrm{a} & . & 2 \mathrm{a} & + \\ 2 \mathrm{~b} & . & . & 2 \mathrm{~m} & . & 1 & 2 \mathrm{a} & 2 \mathrm{a} & . & 2 \mathrm{~b} & 2 \mathrm{~b} & 2 \mathrm{~b} & . & . & + \\ . & . & . & . & . & 1 & . & . & . & 2 \mathrm{~m} & . & 1 & . & . & . \\ . & . & . & . & . & . & . & . & . & . & . & . & . & + & 1 \\ . & . & 1 & . & . & . & . & . & . & . & . & . & . & . & . \\ . & . & . & . & . & . & . & . & 1 & . & . & . & . & 1 & .\end{array}$

Carex pendula

Equisetum telmateia

Vitis vinifera

Alnus glutinosa subsp. glutinosa

Character species of Salicetea purpureae

Brachypodium sylvaticum

Salix amplexicaulis

Rubus caesius

$$
2 \mathrm{~m}+2 \mathrm{~m} \quad 2 \mathrm{~b} \quad 2 \mathrm{~m} \quad 2 \mathrm{~m} \quad 2 \mathrm{~m} \quad 2 \mathrm{~m} \quad 2 \mathrm{~m} \quad 2 \mathrm{~m} \quad 2 \mathrm{a}
$$

Character species of Nerio-Tamaricetea

Tamarix parviflora

Vitex agnus-castus

Nerium oleander subs. oleander

Tamarix sp.

Other species

Piptatherum miliaceum

Equisetum ramosissimum

Corylus avellana

Melilotus indicus

Sanguisorba minor

Calystegia sepium subsp. sepium

Mentha sp.

Anthemis sp.

Clematis vitalba

Cyperus glaber

Polypogon monspeliensis

Trifolium campestre

Carex spicata

Scirpoides holoschoenus 


\begin{tabular}{|c|c|c|c|c|c|c|c|c|c|c|c|c|c|c|c|}
\hline Relevé N. & 1 & 2 & 3 & 4 & 5 & 6 & 7 & 8 & 9 & 10 & 11 & 12 & 13 & 14 & 15 \\
\hline Tripidium ravennae subsp. ravennae & . & . & . & . & . & 1 & . & . & . & . & . & . & $\mathrm{r}$ & . & . \\
\hline Erigeron sumatrensis & . & . & . & . & . & $\mathrm{r}$ & . & . & . & . & & . & + & . & . \\
\hline Dactylis glomerata & . & . & . & . & . & . & . & . & $2 \mathrm{~m}$ & . & . & . & $2 \mathrm{~m}$ & . & \\
\hline Cynodon dactylon & . & . & . & . & . & . & . & . & 1 & . & . & . & . & . & \\
\hline Calamintha nepeta & . & . & . & . & . & . & . & . & $\mathrm{r}$ & . & . & . & . & . & . \\
\hline Verbena officinalis & . & . & . & . & . & . & . & . & $\mathrm{r}$ & . & . & . & $\mathrm{r}$ & . & . \\
\hline Lythrum salicaria & . & . & . & . & . & . & . & . & $\mathrm{r}$ & . & . & . & . & . & \\
\hline Cichorium intibus & . & . & . & . & . & . & . & . & + & . & . & . & . & . & \\
\hline Pulicaria dysenterica & . & + & . & . & . & . & . & . & + & . & . & . & . & . & . \\
\hline Mentha spicata subsp. condensata & . & . & . & . & . & . & . & . & + & . & . & . & . & . & . \\
\hline Solanum nigrum & . & . & . & . & . & . & . & . & . & . & . & . & + & . & . \\
\hline Phragmites australis & . & + & + & . & 1 & . & . & . & . & . & . & . & . & 1 & . \\
\hline Urtica dioica & . & . & . & . & + & . & . & . & . & . & . & . & . & . & . \\
\hline Rumex conglomeratus & . & + & . & . & + & . & . & . & . & . & . & . & . & . & \\
\hline Dittrichia viscosa & . & . & . & . & + & . & . & . & . & . & . & . & . & . & \\
\hline Mentha longifolia & . & . & . & . & + & . & . & . & . & . & . & . & . & . & . \\
\hline Lycopus europaeus & . & . & . & . & + & . & . & . & . & . & . & . & . & . & \\
\hline Arundo donax & . & + & . & . & . & . & . & . & . & . & . & . & . & . & \\
\hline Hedera helix subsp. helix & . & . & 1 & . & . & . & . & . & . & . & . & . & . & . & $2 \mathrm{a}$ \\
\hline Cynanchum acutum subsp. acutum & . & . & . & . & . & . & . & . & . & . & . & . & . & . & . \\
\hline Calamagrostis epigejos & . & . & . & . & . & . & . & . & . & . & . & . & . & + & \\
\hline Arundo plinii & . & . & . & . & . & . & . & . & . & . & . & . & . & 1 & . \\
\hline Ficus carica subsp. carica & . & . & . & . & . & . & . & . & . & . & . & . & . & 1 & \\
\hline Festuca arundinacea & . & . & . & . & . & . & . & . & . & . & . & . & . & . & + \\
\hline Periploca graeca & . & . & . & . & . & . & . & . & . & . & . & . & . & . & 1 \\
\hline
\end{tabular}


Table 5 (Tabela 5): Equiseto telmateide-Platanetum orientalis Bergmeier 1990 (rel. 1-11).

\begin{tabular}{lccccccccccc}
\hline Relevé N. & 1 & 2 & 3 & 4 & 5 & 6 & 7 & 8 & 9 & 10 & 11 \\
\hline Group (Figure 2) & 3 & 3 & 3 & 3 & 3 & 3 & 3 & 3 & 3 & 3 & 3 \\
Plot size $\left(\mathrm{m}^{2}\right)$ & 200 & 200 & 200 & 200 & 200 & 200 & 200 & 200 & 200 & 200 & 200 \\
Total cover $(\%)$ & 90 & 60 & 90 & 80 & 80 & 80 & 90 & 95 & 70 & 70 & 90 \\
Altitude $(\mathrm{m})$ & 58 & 81 & 84 & 80 & 81 & 83 & 88 & 102 & 280 & 82 & 31 \\
Exposure $\left({ }^{\circ}\right)$ & 0 & 0 & 0 & 0 & 0 & 0 & 0 & 0 & 0 & 0 & 0 \\
Slope $\left({ }^{\circ}\right)$ & 0 & 0 & 0 & 0 & 0 & 0 & 0 & 0 & 0 & 0 & 0 \\
Species N. & 10 & 23 & 10 & 16 & 12 & 11 & 15 & 17 & 3 & 10 & 8 \\
\hline
\end{tabular}

Character species of the association

Platanus orientalis

Equisetum telmateia

$\begin{array}{lllllllllll}3 & 4 & 4 & 4 & 4 & 5 & 4 & 4 & 4 & 4 & 4 \\ 4 & . & . & + & + & . & . & . & . & . & . \\ 2 \mathrm{~m} & 3 & 2 \mathrm{~m} & 1 & + & . & . & . & . & . & .\end{array}$

Character species of Platanion orientalis

Equisetum arvense

Character species of Alno glutinosae-Populetea albae

Populus alba

Alnus glutinosa subsp. glutinosa

Humulus lupulus

Character species of Salicetea purpureae

Brachypodium sylvaticum

Rubus caesius

Carex pendula

Carex remota

Salix alba

Character species of Phragmito-Magnocaricetea

Lythrum salicaria

Calystegia sepium subsp. sepium

Lycopus europaeus

Berula erecta

Other species

Carex distans

Juncus inflexus

Calamagrostis epigejos

Dactylis glomerata

Festuca arundinacea

Caucalis platycarpos

Chaerophyllum temulum

Clinopodium vulgare

Corylus avellana

Galium aparine

Helichrysum luteoalbum

Nerium oleander subsp. oleander

Piptaherum miliaceum

Polypogon viridis

Rumex conglomeratus

Tripidium ravennae subsp. ravennae

Tamarix parviflora

Trifolium clypeatum 
Table 6 (Tabela 6): Paspalo distichi-Agrostietum semiverticillati Br.-Bl. 1936 (rel. 1-8), Cyperus fuscus-Juncus hybridus comm. (rel. 9).

\begin{tabular}{lccccccccc}
\hline Relevé N. & 1 & 2 & 3 & 4 & 5 & 6 & 7 & 8 & 9 \\
\hline Group (Figure 2) & 7 & 7 & 7 & 7 & 7 & 7 & 7 & 7 & 8 \\
Plot size $\left(\mathrm{m}^{2}\right)$ & 30 & 30 & 30 & 30 & 10 & 10 & 10 & 10 & 20 \\
Total cover $(\%)$ & 80 & 100 & 80 & 100 & 100 & 100 & 70 & 70 & 40 \\
Altitude $(\mathrm{m})$ & 54 & 84 & 84 & 40 & 82 & 82 & 29 & 32 & 79 \\
Exposure $\left({ }^{\circ}\right)$ & 0 & 0 & 0 & 0 & 0 & 0 & 0 & 0 & 0 \\
Slope $\left({ }^{\circ}\right)$ & 0 & 0 & 0 & 0 & 0 & 0 & 0 & 0 & 0 \\
Species N. & 4 & 5 & 5 & 6 & 6 & 6 & 8 & 9 & 7 \\
\hline
\end{tabular}

Character species of the associations

Paspalum distichum

Cyperus fuscus

Juncus hybridus

\begin{tabular}{|cccccccc|c|}
\hline 5 & 5 & 5 & 5 & 5 & 5 & 4 & 3 &. \\
\hline$\cdot$ &. &. &. &. &. & + & + & $2 \mathrm{~m}$ \\
. &. &. &. &. &. &. &. & $2 \mathrm{~m}$ \\
\cline { 6 - 7 } & & & & & &
\end{tabular}

Character species of Mollinio-Arrhenatheretea

Mentha longifolia

Scirpoides holoschoenus

Agrostis stolonifera

Mentha aquatica

Character species of Isoeto-Nanojuncetea

Juncus articulatus

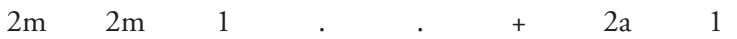

Character species of Phragmito-Magnocaricetea

Lythrum salicaria

Eleocharis palustris subsp. palustris

Alisma plantago-aquatica

Lycopus europaeus

Helosciadium nodiflorum

Veronica anagallis-aquatica subsp. anagallis-aquatica

Character species of Saginetea maritimae

Polypogon maritimus

Centaurium tenuiflorum

Character species of Bidentetea tripartiti

Persicaria hydropiper

Echinochloa crus-galli

Other species

Aster sp.

Daucus carota

Scirpus sp.

Atriplex prostrata

Salix alba

Equisetum arvense

Persicaria maculosa

Cyperus longus

Xanthium strumarium

Dysphania ambrosioides 
Table 7 (Tabela 7): Salsolo kali-Cakiletum maritimae Costa et Mansanet 1981 corr. Rivas-Martinez, Costa \& Loidi 1992 (rel. 1-6), EryngioSporoboletum virginici Géhu et Uslu 1989 (rel. 7-11).

\begin{tabular}{lccccccccccc}
\hline Relevé N. & 1 & 2 & 3 & 4 & 5 & 6 & 7 & 8 & 9 & 10 & 11 \\
\hline Group (Figure 2) & 6 & 6 & 6 & 6 & 6 & 6 & 6 & 6 & 6 & 6 & 6 \\
Plot size $\left(\mathrm{m}^{2}\right)$ & 16 & 16 & 16 & 16 & 16 & 16 & 16 & 16 & 16 & 16 & 16 \\
Total cover $(\%)$ & 20 & 20 & 50 & 60 & 10 & 50 & 100 & 70 & 70 & 70 & 60 \\
Altitude (m) & 0 & 0 & 0 & 0 & 0 & 0 & 0 & 0 & 0 & 0 & 0 \\
Exposure $\left(^{\circ}\right)$ & 0 & 0 & 0 & 0 & 0 & 0 & 0 & 0 & 0 & 0 & 0 \\
Slope $\left({ }^{\circ}\right)$ & 0 & 0 & 0 & 0 & 0 & 0 & 0 & 0 & 0 & 0 & 0 \\
Species N. & 6 & 7 & 6 & 7 & 4 & 5 & 9 & 3 & 10 & 6 & 8 \\
\hline
\end{tabular}

Character species of the associations

Salsola tragus

Cakile maritima subsp. maritima

Elytrigia juncea subsp. juncea

Sporobolus pungens

\begin{tabular}{|cccccc|ccccc|}
\hline $2 \mathrm{~b}$ & $2 \mathrm{a}$ & 3 & 3 & $2 \mathrm{a}$ & $2 \mathrm{~m}$ &. &. & 1 &. & + \\
$\mathrm{r}$ & $2 \mathrm{a}$ & & $2 \mathrm{a}$ & + & &. &. &. &. &. \\
\hline $\mathrm{r}$ & $\cdot$ &. & + &. & $\cdot$ & 4 & $2 \mathrm{~m}$ & 1 & 3 & 3 \\
. &. &. &. &. & $\cdot$ & $2 \mathrm{a}$ & 3 & 3 & & \\
\hline
\end{tabular}

Character species of Cakiletea maritimae

Salsola soda

Suaeda spledens

Euphorbia peplis

$\begin{array}{ccccc}2 \mathrm{~m} & + & 1 & \cdot & . \\ 1 & + & & 2 \mathrm{a} & 1 \\ . & . & 2 \mathrm{~m} & . & .\end{array}$

Character species of Ammophiletea

Elytrigia repens subsp.repens

Eryngium maritimum

Euphorbia paralias

Character species of Lygeo sparti-Stipetea tenacissimae

Matthiola tricuspidata

Anthemis tomentosa

Medicago littoralis

Silene colorata subsp. colorata

Trifolium scabrum

Character species of Salicornietea fruticosae

Sarcocornia perennis

Limonium bellidifolium

Other species

Xanthium strumarium

Atriplex prostrata

Cynodon dactylon

Suaeda maritima

Polygonum maritimum

Trifolium angustifolium

Melilotus indicus

Limonium graecum

Cynanchum acutum subsp. acutum

Elymus sp.

Limonium sp. 
Table 8 (Tabela 8): Sarcocornietum perennis F. Galván \& Santos (rel. 1-5), Puccinellio convolutae-Arthrocnemetum glauci Br.-Bl. (1928) 1933 Géhu ex Géhu (rel. 6-9), Arthrocnemo glauci-Halocnemetum strobilacei Oberdorfer 1952 (rel. 10-12), Limonium narbonense comm. (rel. 13-15).

\begin{tabular}{lccccccccccccccc}
\hline Relevé N. & 1 & 2 & 3 & 4 & 5 & 6 & 7 & 8 & 9 & 10 & 11 & 12 & 13 & 14 & 15 \\
Group (Figure 2) & 4 & 4 & 4 & 4 & 4 & 4 & 4 & 4 & 4 & 4 & 4 & 4 & 4 & 4 & 4 \\
Plot size $\left(\mathrm{m}^{2}\right)$ & 16 & 16 & 16 & 16 & 16 & 16 & 16 & 16 & 16 & 30 & 16 & 25 & 30 & 30 & 50 \\
Total cover $(\%)$ & 90 & 100 & 100 & 90 & 100 & 100 & 100 & 100 & 100 & 100 & 60 & 50 & 100 & 100 & 100 \\
Altitude $(\mathrm{m})$ & 0 & 0 & 0 & 0 & 1 & 0 & 0 & 0 & 0 & 0 & 0 & 0 & 0 & 0 & 0 \\
Exposure $\left(^{\circ}\right)$ & 0 & 0 & 0 & 0 & 0 & 0 & 0 & 0 & 0 & 0 & 0 & 0 & 0 & 0 & 0 \\
Slope $\left(^{\circ}\right)$ & 0 & 0 & 0 & 0 & 0 & 0 & 0 & 0 & 0 & 0 & 0 & 0 & 0 & 0 & 0 \\
Species N. & 6 & 3 & 7 & 6 & 6 & 5 & 3 & 3 & 3 & 2 & 6 & 3 & 7 & 4 & 5 \\
\hline
\end{tabular}

Character species of the associations

Sarcocornia perennis

Arthrocnemum macrostachyum

Halocnemum strobilaceum

Limonium narbonense

\begin{tabular}{|ccccc|ccccccccccc|}
\hline 5 & $2 \mathrm{~b}$ & 3 & 4 & 3 & 1 &. &. &. &. &. &. & $2 \mathrm{~m}$ & $2 \mathrm{~b}$ & $2 \mathrm{~b}$ \\
\hline. &. & $2 \mathrm{~b}$ & + & + & 4 & 4 & 5 & 5 & $2 \mathrm{a}$ & 1 &. &. &. &. \\
. &. &. & + & 1 &. &. &. &. & 5 & 4 & 4 &. &. &. \\
+ &. &. &. &. &. &. &. &. &. &. &. & 5 & 5 & 4 \\
\hline
\end{tabular}

Character species of Salicornietea fruticosae

Puccinelia festuciformis

Halimione portulacoides

Limonium bellidifolium

Limbarda crithmoides subsp. longifolia

Character species of Juncetea maritimi

Tripolium pannonicum subsp. pannonicum

Juncus acutus subsp. acutus

Elytrigia obtusiflora subsp. obtusiflora

Character species of Phragmito-Magnocaricetea

Bolboschoenus maritimus

Phragmites australis

Other species

Polypogon monspeliensis

Aeluropus littoralis

Hordeum marinum

Plantago coronopus

Bupleurum tenuissimum

Suaeda maritima

Limonium sp.

Bupleurum semicompositum

Tamarix tetrandra

$\begin{array}{ccccccccccccccc}2 \mathrm{~m} & 4 & + & + & + & . & 1 & 1 & . & . & + & . & . & + & 1 \\ . & 1 & 2 \mathrm{~b} & . & . & 1 & . & 1 & 1 & . & 1 & . & 1 & 2 \mathrm{~m} & 2 \mathrm{~m} \\ . & \cdot & + & . & . & . & . & . & . & . & + & . & . & . & . \\ \mathrm{r} & . & . & . & . & . & . & . & . & . & . & . & . & . & .\end{array}$


Table 9 (Tabela 9): Juncetum maritimo-acuti Horvatić 1934 (rel. 1-4), Juncus subulatus comm. (rel. 5-8).

\begin{tabular}{lcccccccc}
\hline Relevé $\mathrm{N}$. & 1 & 2 & 3 & 4 & 5 & 6 & 7 & 8 \\
\hline Group (Figure 2) & 4 & 4 & 4 & 4 & 4 & 4 & 4 & 4 \\
Plot size $\left(\mathrm{m}^{2}\right)$ & 16 & 50 & 16 & 16 & 25 & 16 & 50 & 16 \\
Total cover $(\%)$ & 80 & 70 & 80 & 60 & 80 & 100 & 100 & 100 \\
Altitude $(\mathrm{m})$ & 0 & 0 & 0 & 0 & 0 & 0 & 0 & 1 \\
Exposure $\left({ }^{\circ}\right)$ & 0 & 0 & 0 & 0 & 0 & 0 & 0 & 0 \\
Slope $\left({ }^{\circ}\right)$ & 0 & 0 & 0 & 0 & 0 & 0 & 0 & 0 \\
Species $\mathrm{N}$. & 5 & 5 & 7 & 7 & 9 & 6 & 3 & 3 \\
\hline
\end{tabular}

Character species of the associations

Juncus maritimus

Juncus acutus subsp. acutus

Juncus subulatus

\begin{tabular}{|cccc|cccc|}
\hline 4 & 4 &. &. & + &. &. &. \\
. &. & 5 & 3 & 1 & $2 \mathrm{~b}$ &. &. \\
\hline & 1 & + & 1 & 4 & 4 & 4 & 5 \\
\hline
\end{tabular}

Character species of Juncetea maritimi

Tripolium pannonicum subsp. pannonicum Juncus heldreichianus subsp. heldreichianus Elytrigia obtusiflora subsp. obtusiflora

Character species of Salicornietea fruticosae

Puccinellia festuciformis

Sarcocornia perennis

Limonium bellidifolium

Halimione portulacoides

Atriplex prostrata

Limonium hirsuticalyx

Character species of Phragmito-Magnocaricetea

Phragmites australis

Bolboschoenus maritimus

Other species

Tamarix tetrandra

Aeluropus littoralis

Polypogon monspeliensis 
Table 10 (Tabela 10): Phragmitetum communis Schmale 1939 typicum (rel. 4-6), Phragmitetum communis Schmale 1939 elymetosum elongati (rel. 1-3), Phragmitetum communis Schmale 1939 bolboschoenetosum maritimi (rel. 7-8), Typhetum domingensis Brullo, Minissale \& Sampinato 1994 (rel. 9), Bolboschoenus maritimus comm. (rel. 10).

\begin{tabular}{lcccccccccc}
\hline Relevé $N$. & 1 & 2 & 3 & 4 & 5 & 6 & 7 & 8 & 9 & 10 \\
\hline Group $($ Figure 2$)$ & 4 & 4 & 4 & 4 & 4 & 4 & 4 & 4 & 5 & 4 \\
Plot size $\left(\mathrm{m}^{2}\right)$ & 16 & 16 & 16 & 25 & 100 & 16 & 16 & 100 & 16 & 20 \\
Total cover $(\%)$ & 100 & 45 & 90 & 100 & 100 & 100 & 100 & 100 & 50 & 100 \\
Altitude $(\mathrm{m})$ & 2 & 0 & 0 & 0 & 0 & 0 & 0 & 0 & 81 & 0 \\
Exposure $\left({ }^{\circ}\right)$ & 0 & 0 & 0 & 0 & 0 & 0 & 0 & 0 & 151 & 0 \\
Slope $\left({ }^{\circ}\right)$ & 0 & 0 & 0 & 0 & 0 & 0 & 0 & 0 & 15 & 0 \\
Species N. & 7 & 8 & 8 & 3 & 2 & 1 & 7 & 6 & 4 & 7 \\
\hline
\end{tabular}

Character species of the associations

Phragmites australis

Typha domingensis

Bolboschoenus maritimus

\begin{tabular}{|cccccccc|c|c|}
\hline 5 & 4 & 5 & 3 & 5 & 5 & 5 & 5 &. &. \\
\hline &. &. &. &. &. &. & $2 \mathrm{a}$ & $2 \mathrm{~b}$ &. \\
\hline &. &. &. &. &. & $2 \mathrm{a}$ & $2 \mathrm{~m}$ &. & 5 \\
\hline
\end{tabular}

Character species of Phragmito-Magnocaricetea

Calystegia sepium subsp. sepium

Cirsium creticum subsp. creticum

Typha latifolia

Stachys palustris

Lythrum salicaria

Character species of Juncetea maritimi

Elytrigia obtusiflora subsp. obtusiflora

Tripolium pannonicum subsp. pannonicum

Juncus acutus subsp. acutus

Tripidium ravennae subsp. ravennae

Character species of Salicornietea fruticosae

Limonium narbonense

Limbarda crithmoides subsp. longifolia

Sarcocornia perennis

$\begin{array}{cccc}2 \mathrm{a} & + & 2 \mathrm{~b} & \cdot \\ 2 \mathrm{~m} & \cdot & 1 & . \\ . & . & \cdot & 2 \mathrm{~b} \\ . & \cdot & \cdot & 2 \mathrm{a} \\ . & . & . & .\end{array}$

Other species

Cichorium intybus

Rumex patientia

Plantago coronopus

Juncus maritimus

Atriplex prostrata

Polypogon monspeliensis

Suaeda spledens

Tribulus terrestris

Equisetum ramossissimum

Pulicaria dysenterica

Melilotus sp.

Paspalum distichum

Cyperus longus

Rumex conglomeratus

Tamarix tetrandra 